\title{
POLYETHYLENE ENCAPSULATION OF SINGLE-SHELL TANK LOW-LEVEL WASTES \\ ANNUAL PROGRESS REPORT
}

\author{
Paul D. Kalb and Mark Fuhrmann
}

\begin{tabular}{ll}
\multicolumn{2}{c}{ Contributors } \\
James Cassidy & John Heiser, III \\
Peter Colombo & Paul D. Kalb \\
Eena-Mai Franz & John Klages \\
Mark Fuhrmann & Richard Pietrzak
\end{tabular}

September 1992

Prepared for the

Underground Storage Tank Integrated Demonstration

Office of Technology Development

U.S. Department of Energy

DEPARTMENT OF NUCLEAR ENERGY

BROOKHAVEN NATIONAL LABORATORY, ASSOCIATED UNIVERSITIES, INC. UPTON, NEW YORK 11973 


\section{DISCLAIMER}

This report was prepared as an account of work sponsored by an agency of the United States Government. Neither the United States Government nor any agency thereof, nor any of their employees, nor any of their contractors, subcontractors, or their employees, makes any warranty, express or implied, or assumes any legal liability or responsibility for the accuracy, completeness, or usefulness of any information, apparatus, product, or process disclosed, or represents that its use would not infringe privately owned rights. Reference herein to any specific commercial product, process, or service by trade name, trademark, manufacturer, or otherwise, does not necessarily constitute or imply its endorsement, recommendation, or favoring by the United States Government or any agency, contractor or subcontractor thereof. The views and opinions of authors expressed herein do not necessarily state or reflect those of the United States Government or any agency, contractor or subcontractor thereof.

Printed in the United States of America

Available from

National Technical Information Service

U.S. Department of Commerce

5285 Port Royal Road

Springfield, VA 22161

NTIS price codes:

Printed Copy: A04; Microfiche Copy: A01 


\section{ABSTRACT}

This report describes work supported by the UST-ID, conducted at Brookhaven National Laboratory (BNL), to develop and demonstrate a polyethylene waste encapsulation process for lowlevel radioactive (LLW) and hazardous mixed wastes (HMW) stored in underground tanks. During FY 1992, studies were completed on the effects of elevated temperature on waste form integrity, strength and leachability. No changes in waste form integrity or compressive yield strength were detected after storing polyethylene waste forms containing 50,60 and 70 wt\% sodium nitrate at $70^{\circ} \mathrm{C}$ for 3 months. Leaching of polyethylene waste forms with similar nitrate salt loadings at temperatures up to $70^{\circ} \mathrm{C}$ resulted in slight increases in leachability ( $<$ a factor of 2), compared with leaching at ambient temperatures. Leaching of sodium nitrate from polyethylene waste forms was diffusion-controlled, enabling extrapolation of laboratory leach data to full-scale waste forms over long time periods. Full-scale polyethylene waste forms containing 50 to $70 \mathrm{wt} \%$ nitrate salt could be expected to leach a total of $5 \%$ to $17 \%$ of the original contaminant source term after 300 years of leaching under worst-case $\left(70^{\circ} \mathrm{C}\right.$, fully saturated) conditions. This is about 25 to 75 times lower leachability than conventional cement grout waste forms containing a maximum of $20 \mathrm{wt} \%$ nitrate salts. 


\section{Table of Contents}

1. INTRODUCTION $\ldots \ldots \ldots \ldots \ldots \ldots \ldots \ldots \ldots \ldots \ldots \ldots \ldots \ldots \ldots \ldots \ldots$

1.1 The Polyethylene Encapsulation Process $\ldots \ldots \ldots \ldots \ldots \ldots$

1.2 Characterization of Single Shell Tank Wastes $\ldots \ldots \ldots \ldots \ldots$

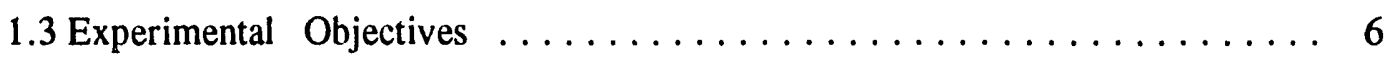

2. PROCESSING AND SAMPLE PREPARATION $\ldots \ldots \ldots \ldots \ldots \ldots \ldots \ldots \ldots \ldots$

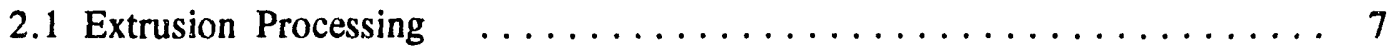

2.2 Leach Test Specimen Preparation $\ldots \ldots \ldots \ldots \ldots \ldots \ldots \ldots$

2.3 Thermal Effects Specimen Preparation $\ldots \ldots \ldots \ldots \ldots \ldots \ldots$

3. LEACHABILITY AT ELEVATED TEMPERATURES $\ldots \ldots \ldots \ldots \ldots \ldots \ldots \ldots$

3.1 Leach Test Method $\ldots \ldots \ldots \ldots \ldots \ldots \ldots \ldots \ldots$

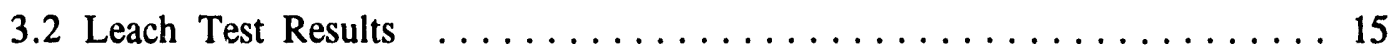

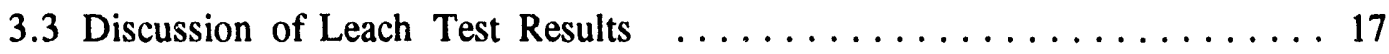

3.4 Conclusions Regarding Waste Form Leaching ............. 19

4. THERMAL EFFECTS ON WASTE FORM STRENGTH AND INTEGRITY $\ldots \ldots \ldots 32$

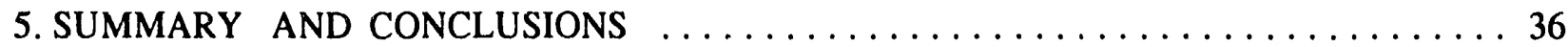

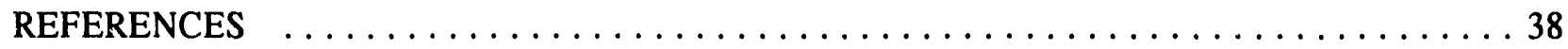

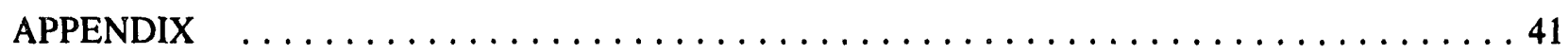




\section{List of Tables}

Table 1.1 Estimated Mass of Nonradioactive Chemical Components of Existing SST

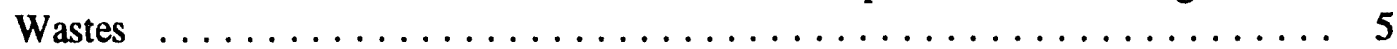

Table 3.2. Accelerated Leach Test Results Conducted at $20^{\circ} \mathrm{C}$ for $\mathrm{NaNO}_{3}$ Encapsulated

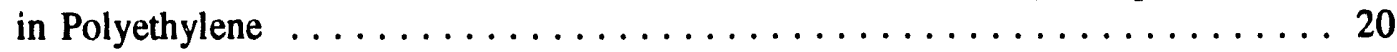

Table 3.3 Accelerated Leach Test Results Conducted at $35^{\circ} \mathrm{C}$ for $\mathrm{NaNO}_{3}$ Encapsulated

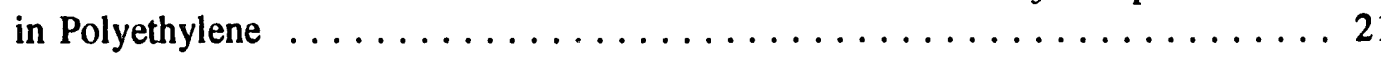

Table 3.4. Accelerated Leach Test Results Conducted at $50^{\circ} \mathrm{C}$ for $\mathrm{NaNO}_{3}$ Encapsulated

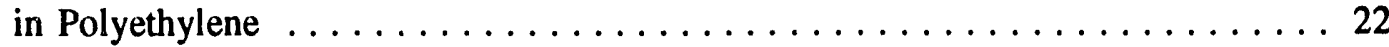

Table 3.5 Accelerated Leach Test Results Conducted at $70^{\circ} \mathrm{C}$ for $\mathrm{NaNO}_{3}$ Encapsulated

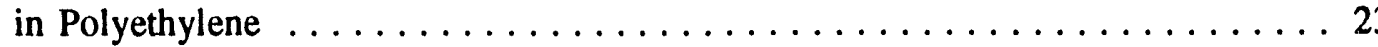

Table 3.6 Projected Cumulative Fractional Releases After 300 Years of Leaching for Full-Scale Polyethylene Waste Forms Containing Nitrate Salt Wastes . . . . . 24

Table 4.1 Compressive Yield Strength for UST-ID Polyethylene Waste Forms Containing Sodium Nitrate Stored at Elevated and Ambient Temperatures 


\section{List of Figures}

Figure 2.1 The BNL bench-scale extruder, equipped with two volumetric feeders calibrated to deliver precise quantities of simulated waste and polyethylene binder. ............................... 8

Figure 2.2 Calibration curve for sodium nitrate simulated waste in terms of feeder output $(\mathrm{g} / \mathrm{min})$ as a function of percent full speed. . . . . . . . . . . 9

Figure 2.3 Calibration curve for low-denisty polyethylen: binder in terms of feeder output $(\mathrm{g} / \mathrm{min})$ as a function of percent full speed. $\ldots \ldots \ldots \ldots \ldots \ldots$

Figure 3.1 A schematic of the concepts used to combine experimental and modeling

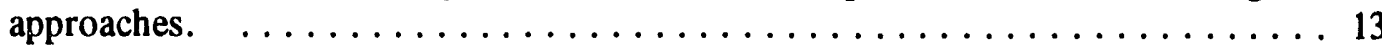

Figure 3.2 Accelerated Leach Test results for polyethylene waste forms with sodium

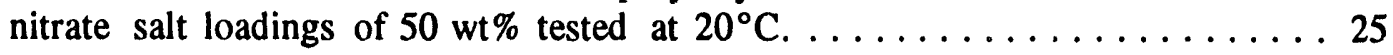

Figure 3.3 Accelerated Leach Test results for polyethylene waste forms with sodium nitrate salt loadings of $60 \mathrm{wt} \%$ tested at $20^{\circ} \mathrm{C} \ldots \ldots \ldots \ldots \ldots$

Figure 3.4 Accelerated Leach Test results for polyethylene waste forms with sodium nitrate salt loadings of $70 \mathrm{wt} \%$ tested at $20^{\circ} \mathrm{C} \ldots \ldots \ldots \ldots \ldots$

Figure 3.5 Accelerated Leach Test results for polyethylene waste forms with sodium

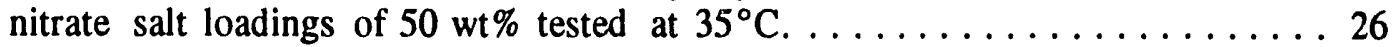

Figure 3.6 Accelerated Leach Test results for polyethylene waste forms with sodium

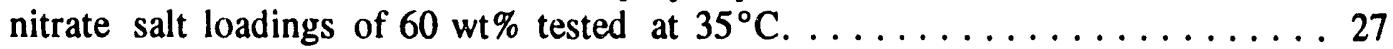

Figure 3.7 Accelerated Leach Test results for polyethylene waste forms with sodium nitrate salt loadings of $70 \mathrm{wt} \%$ tested at $35^{\circ} \mathrm{C} \ldots \ldots \ldots \ldots \ldots \ldots$

Figure 3.8 Accelerated Leach Test results for polyethylene waste forms with sodium nitrate salt loadings of $50 \mathrm{wt} \%$ tested at $50^{\circ} \mathrm{C} \ldots \ldots \ldots \ldots \ldots$

Figure 3.9 Accelerated Leach Test results for polyethylene waste forms with sodium nitrate salt loadings of $60 \mathrm{wt} \%$ tested at $50^{\circ} \mathrm{C} \ldots \ldots \ldots \ldots 28$

Figure 3.10 Accelerated Leach Test results for polyethylene waste forms with sodium nitrate salt loadings of $70 \mathrm{wt} \%$ tested at $50^{\circ} \mathrm{C} \ldots \ldots \ldots \ldots \ldots 29$ 


\section{List of Figures (cont.)}

Figure 3.11 Accelerated Leach Test results for polyethylene waste forms with sodium nitrate salt loadings of $50 \mathrm{wt} \%$ tested at $70^{\circ} \mathrm{C} \ldots \ldots \ldots \ldots \ldots \ldots$

Figure 3.12 Accelerated Leach Test results for polyethylene waste forms with sodium nitrate salt loadings of $60 \mathrm{wt} \%$ tested at $70^{\circ} \mathrm{C} \ldots \ldots \ldots \ldots \ldots \ldots \ldots$

Figure 3.13 Accelerated Leach Test results for polyethylene waste forms with sodium nitrate salt loadings of $70 \mathrm{wt} \%$ tested at $70^{\circ} \mathrm{C} \ldots \ldots \ldots \ldots$

Figure 3.14 Relationship of leachability (CFL) as a function of waste loading at $20^{\circ} \mathrm{C}$,

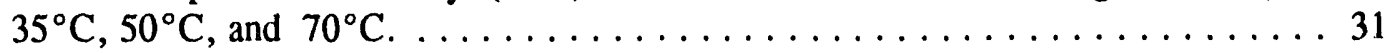

Figuie 3.15 Arrhenius plot of the natural log of diffusion coefficients for polyethylene waste forms containing sodium nitrate plotted as a function of inverse leaching temperature in kelvins. .................. 31

Figure 4.1 Typical compressive yield . tress data plotted as a function of time for 5 replicate polyethylene waste form specimens containing sodium nitrate (60 wt\% $\mathrm{NaNO}_{3}$,

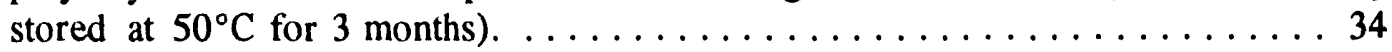

Figure 4.2 Compressive yield strength for UST-ID polyethylene waste forms containing sodium nitrate stored at elevated and ambient temperatures. ......... 34

Figure 4.3 Percent of original compressive strength for polyehtylene waste forms

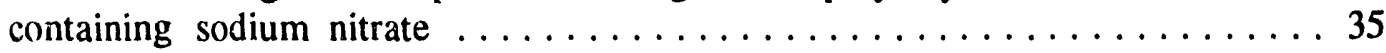




\section{INTRODUCTION}

For the past 50 years, the U.S. Depariment of Energy (DOE) and its predecessor agencies have stored large volumes of defense-related radioactive and mixed wastes in underground tanks. Initially, these tanks were constructed of single steel walls surrounded by reinforced concrete and are known as single-shell tanks (SSTs). Over time, the highly corrosive contents caused rnany of the tanks to begin to leak.

As part of its effort to remediate leaking and potentially leaky tanks, DOE's Office of Technology Development (OTD) has established the Underground Storage Tank Integrated Demonstration (UST-ID). The overall objectives of the UST-ID include facilitating the development and demonstration of enhanced technologies that will lead to improved treatment and stabilization of underground storage tank wastes. The host site for the UST-ID is Hanford, but the program addresses potential use of these emerging technologies in remediation of tanks at five DOE facilities: Hanford, Fernald, Idaho (Idaho National Engineering Laboratory), Oak Ridge, and Savannah River. In order to meet its objectives, the UST-ID supports technology development in six focus areas including: 1) waste characterization, 2) high- and low-level waste treatment and disposal, 3) retrieval, transfer, and storage, 4) waste separation, 5) in situ treatment and disposal, and 6) site closure. [1] The Hanford Federal Facility Agreement and Consent Order (Tri-Party Agreement) mandates that a demonstration of a full-scale SST closure be completed by 2004 . An interim milestone includes identification of closure methods including waste treatment and disposal by 1999.[2] In an effort to meet these milestones, the UST-ID is supporting efforts to develop technologies leading to successful treatment and stabilization of SSTs.

This report describes work supported by the UST-ID, conducted at Brookhaven National Laboratory (BNL), to develop and demonstrate a polyethylene waste encapsulation process for lowlevel radioactive (LLW) and hazardous mixed wastes (HMW) stored in underground tanks. 


\subsection{The Polyethylene Encapsulation Process}

The polyethylene process was developed several years ago at BNL for solidification of LLW such as evaporator concentrate salts and ion exchange resins.[3,4] Recently, it has been successfully applied for treatment of hazardous and mixed waste streams such as sodium nitrate salts and sludges.[5,6] Polyethylene is an inert thermoplastic material with a melting point of $120^{\circ} \mathrm{C}$ and processing temperature range of $120-150^{\circ} \mathrm{C}$. As such, it is not susceptible to chemical interactions between the waste and binder and always results in a monolithic solid waste form on cooling. In contrast, grout solidification processes (currently considered the base-line technology for SST LLW) require a chemical hydration reaction for setting and curing. Thus, cement binders are susceptible to chemical interactions with the waste that can limit both the types of waste that are compatible and the amount of waste that can be incorporated. Small variations in waste composition during processing (which are likely based on the heterogeneous nature of SST LLW) may require frequent adjustment of solidification formulations and quality control testing. Polyethylene processing is less dependent on waste chemistry, enabling a wider range of acceptable waste types, improved waste loadings, and easier processing under heterogeneous waste conditions. In general, polyethylene encapsulation can be accomplished with greater efficiency (more waste encapsulated per drumi) and with better waste form performance than is possible using conventional encapsulation technologies such as hydraulic cement-based grouts. For example, as much as 70 dry wt\% sodium nitrate can be encapsulated in polyethylene, compared with $13-20 \mathrm{wt} \%$ in portland cement.

Extensive waste form performance testing has been completed including compressive strength, water immersion, thermal cycling, radioactive and hazardous constituent leachability, radiation stability and biodegradation.[3,6,7] In each case, waste form performance exceeded regulatory criteria by a wide margin. Scale-up feasibility has been confirmed by processing simulated nitrate wastes at product output rates up to $900 \mathrm{~kg} / \mathrm{hr}(2000 \mathrm{lbs} / \mathrm{hr})$. Based on results of bench-scale processing and performance testing, a production-scale technology demonstration of the polyethylene encapsulation process for nitrate salt wastes is planned under a parallel BNL effort, the Polymer Solidification Program, sponsored by DOE OTD. 
Polyethylene encapsulation has been identified as a potential treatment option for SST LLW at Hanford by several Westinghouse Hanford Co. (WHC) and independent investigations including: the "Technology Program Plan for Closure of the Single-Shell Tank Operable Units"[8], the "Third Party Technical Workshop on Hanford SST Waste and Residuals"[9], the WHC "Systems Engineering Study for the Closure of Single-Shell Tanks"[10], the "Preliminary Assessment of Candidate Immobilization Technologies for Retrieved Single-Shell Tank Wastes"[11], and the "Tank Waste Remediation System (TWRS) LLW Disposal Technology Working Group".[12]

\subsection{Characterization of Single Shell Tank Wastes}

The UST-ID Program encompasses more than 332 underground storage tanks with a total volume capacity in excess of $750,000 \mathrm{~m}^{3}\left(1.98 \times 10^{8} \mathrm{gal}\right.$.). The USTs range in size from 0.114 to $7,500 \mathrm{~m}^{3}$ (30 gal. to 2 million gal.), with an average volume between 1,890 and $3,790 \mathrm{~m}^{3}$ ( 0.5 to 1 million gal.). The overall volume of wastes currently stored in USTs at the five DOE sites is about $370,000 \mathrm{~m}^{3}$ (98 million gal.).[13]

The Hanford site contains 149 SSTs used until 1971 for storage of highly radioactive and chemically hazardous liquid wastes and sludges. T hey comprise about $62 \%$ of the total volume of wastes currently stored in USTs at the five DOE sites.[13] Approximately half the tanks are currently leaking. They contain about $200,000 \mathrm{MT}$ of waste (predominantly sodium nitrate) with a total radioactive inventory of about $60 \mathrm{MCi}$. Table 1.1 provides an estimate of the nonradioactive chemical constituents and their relative quantities found in a typical SST following jet pumping to remove supernatant liquid. Most of the activity results from Cs-137 ( 20\%) and Sr-90 ( $78 \%)$ and their daughter products.[14] Typically, tanks contain about one million gallons of saltcake $(\sim 35$ $w t \%)$, sludge $(\sim 60 \mathrm{wt} \%)$ and interstitial liquid $(\sim 5 \mathrm{wt} \%)$. The high loadings of fission products in a typical tank result in radiation dose rates of 300 to $700 \mathrm{rad} / \mathrm{hour}$ and temperatures ranging from 51 to $63^{\circ} \mathrm{C}$. 11 of the 149 SSTs have been designated as "High Heat Load" tanks. Estimated heat loads in these tanks range from 11.72 to $43.96 \mathrm{~kW}(42,000$ to $150,000 \mathrm{BTU} /$ hour $)$ resulting in temperatures measured between 37 and $92^{\circ} \mathrm{C}$. [15] 
Several options for SST waste processing prior to solidification in a final waste form are currently under consideration. These include: 1) sludge washing in which sludges and solids are separated from supernatant liquids and then washed in caustic solutions to remove soluble salts, 2) TRUEX processing in which solids are dissolved in acid and the TRU constituents are removed using the TRUEX process, and 3) the null alternative in which no isotopic separation is performed and tank wastes are homogenized in a lag storage area prior to solidification. The first two options involve partitioning of the SST wastes into a large volume low-level waste fraction and a small volume high level and/or transuranic waste fraction. The sludge washing option would result in a volume reduction of the fission products in the LLW, thus reducing the thermal load of these wastes. The null alternative would not reduce the fission product fraction, but would result in a more even distribution of the heat load, dampening out peak heat loads evident in the "High Heat Load" tanks. Assuming the null alternative is chosen and no further radionuclide separation is conducted, an anticipated average temperature range of $50-70^{\circ} \mathrm{C}$ is assumed for the purposes of this investigation. 
Polyethylene Encapsulation of SST LLW Annual Report

Table 1.1 Estimated Mass of Nonradioactive Chemical Components of Existing SST Wastes ${ }^{(a)}$

\begin{tabular}{|c|c|c|c|}
\hline Chemical & Total Bulk Sludge (t) & Total Bulk Saltcake (t) & Interstitial Liquid ( $\mathrm{t}$ ) \\
\hline $\mathrm{NaNO}_{3}$ & 20,000 & 110,000 & 2,500 \\
\hline $\mathrm{NaNO}_{2}$ & 3,000 & 2,300 & 1,900 \\
\hline $\mathrm{Na}_{2} \mathrm{CO}_{3}$ & 1,700 & 730 & 70 \\
\hline $\mathrm{NaOH}$ & 4,200 & 2,000 & 740 \\
\hline $\mathrm{NaAlO}_{2}$ & 950 & 1,900 & 1,500 \\
\hline $\mathrm{Na}_{2} \mathrm{SO}_{4}$ & 740 & 1,700 & \\
\hline $\mathrm{Na}_{3} \mathrm{PO}_{4}$ & 12,500 & 2,100 & 280 \\
\hline Cancrinite & 2,700 & & \\
\hline $\mathrm{Al}(\mathrm{OH})_{3}$ & 2,300 & & \\
\hline $\mathrm{Ce}(\mathrm{OH})_{3}$ & 320 & & \\
\hline $\mathrm{Cr}(\mathrm{OH})_{3}$ & 190 & & \\
\hline $\mathrm{Cd}(\mathrm{OH})_{2}$ & 5 & & \\
\hline $\mathrm{Fe}(\mathrm{OH})_{3}$ & 1,200 & & \\
\hline $\mathrm{Sr}(\mathrm{OH})_{2}$ & 50 & & \\
\hline $\mathrm{BiPO}_{4}$ & 380 & & \\
\hline $\mathrm{CaCO}_{3}$ & 320 & & \\
\hline $\mathbf{F}^{-}$ & 800 & & 5 \\
\hline $\mathrm{Cl}^{-}$ & 40 & & \\
\hline $\mathrm{Hg}^{+}$ & 0.9 & & \\
\hline $\mathrm{MnO}_{2}$ & 190 & & \\
\hline $\mathrm{Ni}_{2} \mathrm{Fe}(\mathrm{CN})_{6}$ & 500 & & \\
\hline $\mathrm{P}_{2} \mathrm{O}_{5} \bullet 24 \mathrm{WO}_{2} \bullet 44 \mathrm{H}_{2} \mathrm{O}$ & 20 & & \\
\hline $\mathrm{ZrO}_{2} \cdot 2 \mathrm{H}_{2} \mathrm{O}$ & 430 & & \\
\hline Organic Carbon & & & 200 \\
\hline $\mathrm{H}_{2} \mathrm{O}$ & 26,000 & 14,000 & 4,800 \\
\hline TO'TAL & 79,000 & 135,000 & 12,000 \\
\hline
\end{tabular}

a) This table taken from Reference [13] 


\subsection{Experimental Objectives}

Although Hanford SST wastes are similar in chemical composition to other nitrate wastes within DOE (e.g., Rocky Flats Plant, Oak Ridge, Savannah River Plant and West Valley) the high concentrations of fission products and resulting high thermal loads (assuming fission products are not separated out of the waste) represent unique conditions that potential final waste forms must meet. Because of these unique properties, the objective of Phase I of this effort is to investigate the potential impacts of residual heat and high radiation doses on key waste form properties including mechanical integrity, strength, and leachability. During FY 1992, studies were completed on the effects of elevated temperature on waste form integrity, strength and leachability. In FY 1993, testing is planned to investigate the effects of elevated temperature on mechanical creep and potential synergistic effects of temperature and radiation doses.

If Phase I testing of simulated waste forms indicates satisfactory performance under anticipated thermal conditions, the second phase will be initiated. This work, will determine pretreatment requirements, acceptable waste form formulations, and quality assurance/quality control specifications. Phase II development efforts will be conducted using non-radioactive surrogate waste that closely resembles actual SST waste in both chemical and physical characteristics. Surrogate waste and/or recipes for producing surrogates will be coordinated with other UST-ID projects investigating waste characterization. The final phase of this effort (Phase III), will involve confirmation of scale-up feasibility, and completion of a full-scale demonstration of polyethylene encapsulation of surrogate SST nitrate salts. 


\section{PROCESSING AND SAMPLE PREPARATION}

\subsection{Extrusion Processing}

Samples were prepared using a bench-scale plastics extruder with a $32 \mathrm{~mm}(1.25 \mathrm{in}$.) screw diameter and a maximum output rate of about $35 \mathrm{~kg} / \mathrm{hr}(16 \mathrm{lb} / \mathrm{hr})$. The BNL extrudsr, shown in Figure 2.1, is equipped with two volumetric feeders calibrated to deliver precise quantities of simulated waste and polyethylene binder. The materials are mixed and heated at about $150{ }^{\circ} \mathrm{C}$ within the extruder, forming a homogeneous molten mixture. The mixture is then extruded into a suitable mold and forms a monolithic solid waste form on cooling.

Separate feeders for the polyethylene and simulated salt waste were calibrated using the materials that were employed for test specimens. Each feeder was calibrated at five different speeds covering the complete operating range $(10,25,5075$ and $90 \%$ of full speed). Output rate at each speed was measured for at least 10 trials. Mean output rates, associated $2 \sigma$ error, and linear regression lines were calculated. Calibration results are shown in Figures 2.2 and 2.3 in terms of feeder output $(\mathrm{g} / \mathrm{min})$ as a function of percent full speed. Feeder calibration data are included in the Appendix.

\subsection{Leach Test Specimen Preparation}

The waste forms prepared for leach tests were mixtures of $\mathrm{NaNO}_{3}$ and low-density polyethylene, with nominal salt loadings of 50,60 and $70 \mathrm{wt} \%$. Mixtures were extruded into polyvinyl chloride (PVC) molds measuring $2.5 \mathrm{~cm} \mathrm{I.D.} \times 15 \mathrm{~cm}$ in length. After cooling, the extruded rods were cut to form the leaching specimens, measuring $2.5 \mathrm{~cm}$ in diameter $\times 2.5 \mathrm{~cm}$ in height, as per Accelerated Leach Test recommendations. Cut surfaces at the tops and bottoms of test specimens exposed unencapsulated salt to leachate and thus were re-sealed by heating to more closely replicate the normally sealed surfaces of cast waste forms. 


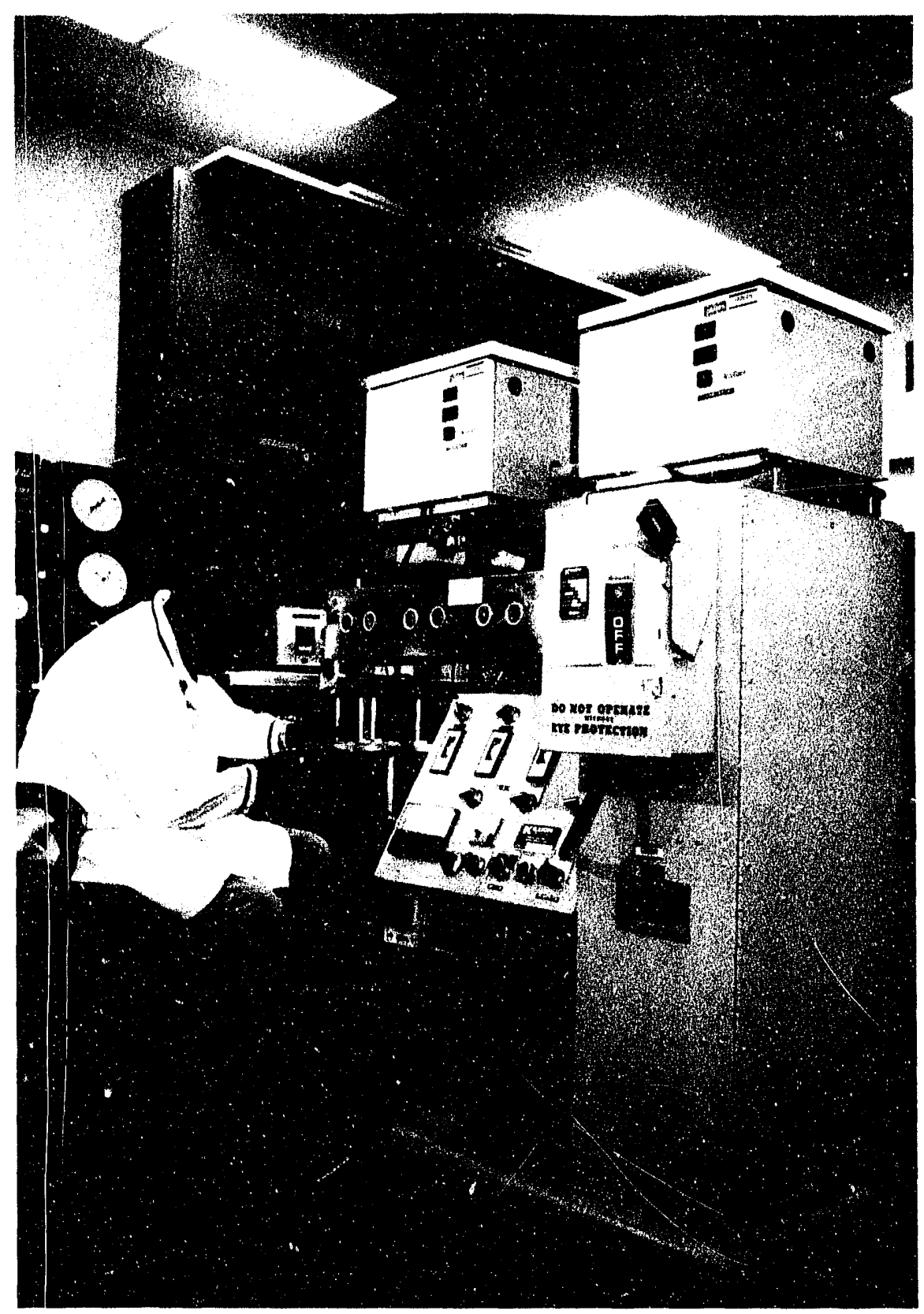

Figure 2.1 The BNL bench-scale extruder, equipped with two volumetric feeders calibrated to deliver precise quantities of simulated waste and polyethylene binder. 


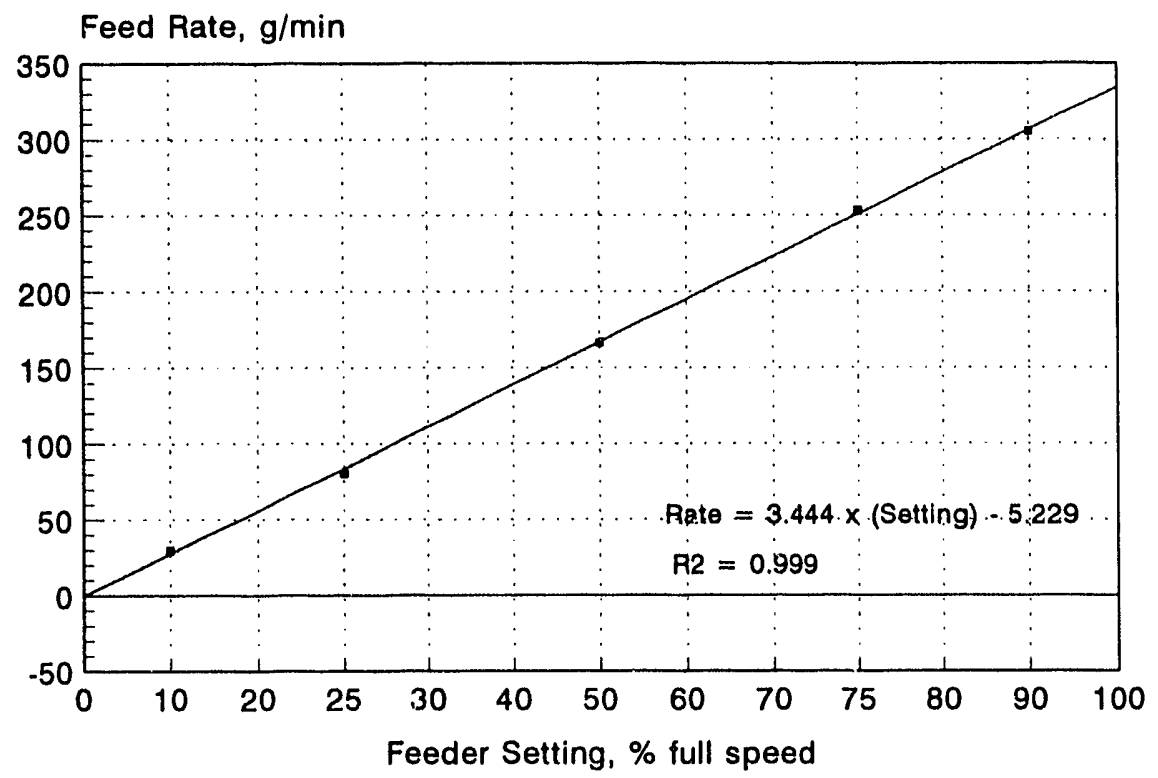

Figure 2.2 Calibration curve for sodium nitrate simulated waste in terms of feeder output $(\mathrm{g} / \mathrm{min})$ as a function of percent full speed.

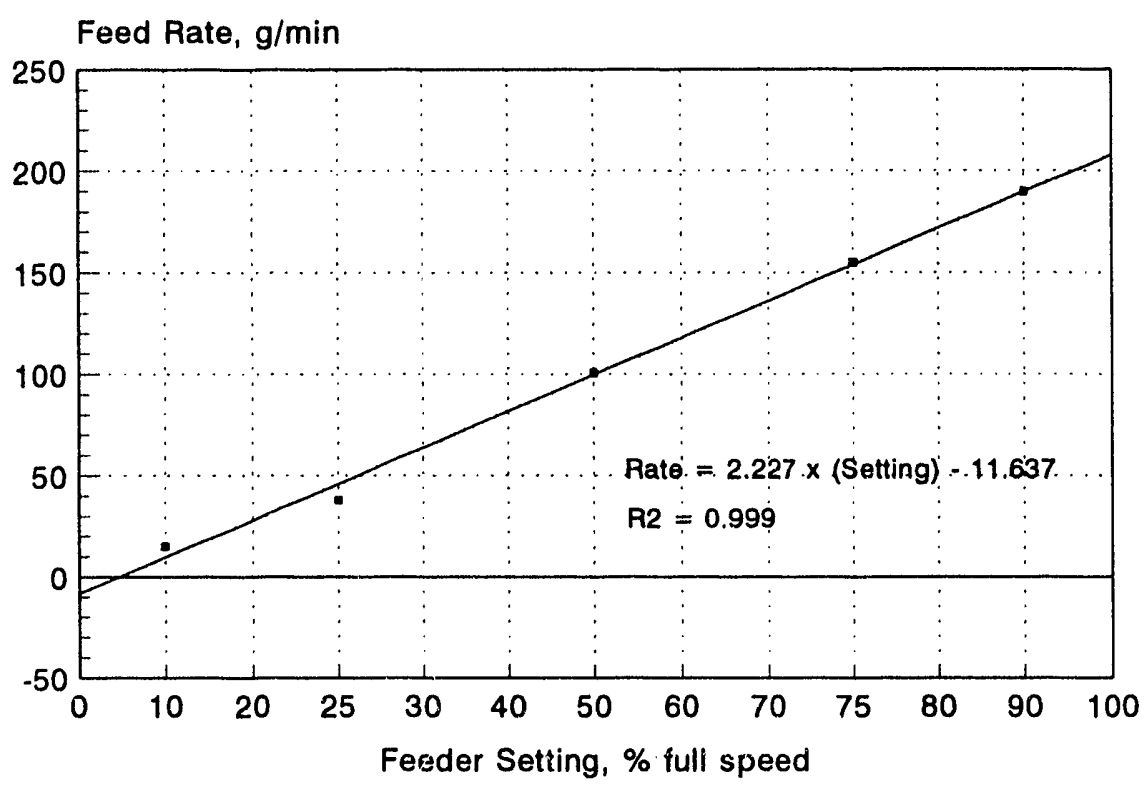

Figure 2.3 Calibration curve for low-denisty polyethylene binder in terms of feeder output $(\mathrm{g} / \mathrm{min})$ as a function of percent full speed. 
Leach test specimens were then weighed and dimensioned. Densities were calculated in order to compare homogeneity among samples and determine sodium levels for use as the source term in leaching calculations.

\subsection{Thermal Effects Specimen Preparation}

Simulated waste forms containing 50,60 and $70 \mathrm{wt} \%$ sodium nitrate encapsulated in polyethylene were prepared for examining the effects of elevated temperatures on waste form integrity and mechanical strength. Waste form preparation technique for these specimens was similar to the procedure described above, except that test specimens were extruded into polyethylene molds inserted in copper sleeves which provided a heat sink. Nominal dimensions for these test specimens were $50 \mathrm{~mm}$ diameter $\times 100 \mathrm{~mm}$ height. Approximately 40 replicates were made at each waste loading.

In preparation for compressive strength testing, top and bottom surfaces of test specimens were machined to form right cylinders with smooth surfaces. Densities were calculated from dimension and weight data. Average densities were $1.280 \pm .005$ (50 wt\% salt), $1.371 \pm .005$ (60 wt\% salt), and $1.544 \pm .011$ (70 wt\% salt). Data are included in the Appendix. 


\section{LEACHABILITY AT ELEVATED TEMPERATURES}

A critical parameter of waste form performance is the rate at which a contaminant is released under aqueous conditions such as a saturated disposal facility. Release rates are quantified by conducting a leach test in which waste forms, containing a known amount of contaminant, are suspended in an aqueous solution. The concentration of contaminant entering the solution is determined and the fractional quantity of contaminant released over time is calculated in terms of the incremental fracticn :elease (IFL). The sum of the IFLs is the cumulative fraction release (CFL), and the CFL divided by cumulative leach time is the release ratt. Under certain test conditions, the mechanism by which leaching occurs also can be determined.

A comprehensive investigation of the leachability of $\mathrm{Na}$ from polyethylene waste forms containing $\mathrm{NaNO}_{3}$ was conducted for this study. This salt is used as a simulant for Hanford singleshell tank waste. As described in Section 1.2, actual SST wastes contain a wide range of constituents, but $\mathrm{NaNO}_{3}$ is the predominant component, accounting for about $38 \mathrm{wt} \%$ of the sludge, $81 \mathrm{wt} \%$ of the saltcake, and $35 \mathrm{wt} \%$ of the interstitial liquid. Since the polyethylene process is based on microencapsulation in an inert binder, no chemical reactions take place between the waste and the polyethylene. Thus, releases of sodium will be similar to those of any other highly soluble species such as cesium.

The objectives of the leaching study were to:

(1) determine leach rates of $\mathrm{NaNO}_{3}$ /polyethylene waste forms at several waste loadings

(2) determine leach rates at temperatures as high as $70^{\circ} \mathrm{C}$ which is the maximum projected temperature of this self-heating waste

(3) determine the leaching mechanism of $\mathrm{NaNO}_{3}$ /polyethylene waste forms and attempt to predict releases.

The Accelerated Leach Test (ALT) used for this study was recently developed at BNL. It 
is particularly well suited for this application since it was designed to be run at elevated temperatures.[16] It provides an accelerated determination of the maximum leachability of solidified waste. The ALT method is applicable to any material that does not degrade, deform, or in which there is no change in the mechanism of leaching during the test.

The data obtained with this test can be used to model long-term releases from waste forms, or to extrapolate from laboratory-scale waste forms if diffusion is the dominant leaching mechanism. Diffusion can be confirmed as the leaching mechanism by comparing experimental leach data with predicted releases using a computerized mathematical model for diffusion written to accompany this test. The program, and a User's Guide that gives screen-by-screen instructions on the use of the program, are available.[17] The models used in the program include:

- diffusion from an infinite slab

- diffusion from a finite cylinder

- $\quad$ solubility limited release

- diffusion plus partitioning

The results do not apply to releases in specific disposal environments unless tests are conducted to determine the leaching mechanism under those conditions. Projections of releases assume the long-term stability of the waste form which may not be revealed adequately by shortterm tests.

The Accelerated Leach Test is a semi-dynamic leach test, i.e., the leachant is sampled and replaced periodically. Parameters such as temperature, leachant volume, and specimen size are used to obtain releases that are accelerated relative to other standard leach tests and to the leaching of full-scale waste forms.

The results of this accelerated test can be extrapolated to long times if the data from tests run at high temperatures and those run at the reference temperature $\left(20^{\circ} \mathrm{C}\right)$ can be modeled by diffusion. A computer program plots the experimental data and a curve calculated from an effective 
diffusion coefficient for diffusion from a finite cylinder (Figure 3.1). If the data from the accelerated tests, the reference test, and the modeled curve fit within the criteria, diffusion is taken to be the leaching mechanism. In this case, the model can be used to project releases from fullscale waste forms for long times. The accelerated test provides a measure of the maximum fractional release to which the modeled data can be extrapolated. By generating data over a specified temperature range, an Arrhenius plot can be produced, allowing projections at temperatures other than those tested. If the diffusion model does not adequately fit the data, other models (diffusion plus partitioning and solubility limited) can be used to suggest the leaching mechanism that controls releases; no extrapolations are allowed with these models. If no model fits the data, then an alternative graphical comparison of the data is recommended. A linear plot of modeled cumulative fraction leached (CFL) plotted against experimental CFL verifies that the accelerated data is comparable to the reference data, showing that the accelerated test is appropriate. However, no extrapolation of data can be made with this technique.

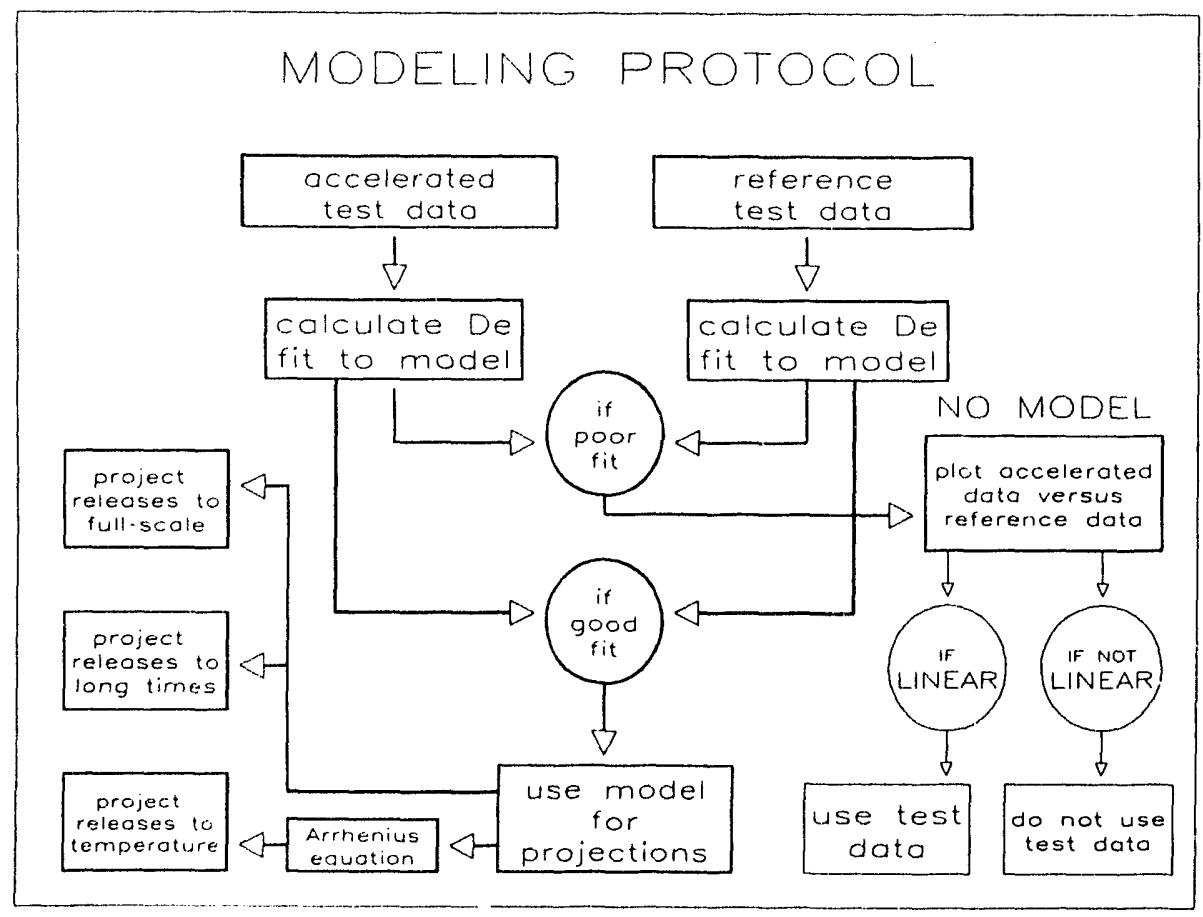

Figure 3.1 A schematic of the concepts used to combine experimental and modeling approaches. 


\subsection{Leach Test Method}

The waste forms tested were mixtures of $\mathrm{NaNO}_{3}$ and polyethylene with nominal salt loadings of 50,60, and $70 \mathrm{wt} \%$. Test specimens were prepared with right cylinder geometries to a nominal final dimension of $2.5 \mathrm{~cm}$ diameter by $2.5 \mathrm{~cm}$ in length. Details on sample preparation are described in Section 2.2. The quantity of $\mathrm{Na}$ contained in each leach test specimen (source term) was determined by measurement of the sample density. These values were compared to a plot of theoretical density versus salt loading. Although the theoretical plot was a parabolic mixing function the segment of interest was sufficiently small that a linear equation described the segment adequately. The linear equation was then used to calculate the percentage of salt in each sample based on its measured density.

Three liters of distilled water were used for each sampling interval. Leaching tests were conducted at $20^{\circ} \mathrm{C}, 35^{\circ} \mathrm{C}, 50^{\circ} \mathrm{C}$, and $70^{\circ} \mathrm{C}$. Elevated temperature leaching was conducted in a forced air convection environmental chamber with a temperature control of $\pm 0.5^{\circ} \mathrm{C}$. Fresh leachant was pre-heated in the chamber for 24 hours prior to immersing test specimens. Four replicate samples were tested for each salt loading at each temperature (a total of 48 specimens leached). Sampling times and leachant replacement intervals are specified in Table 3.1. Leachate analysis for $\mathrm{Na}$ concentration was done by atomic absorption (AA) spectroscopy. 
Table 3.1. Leachant Replacement Intervals for the ALT

\begin{tabular}{|c|c|c|}
\hline Interval & Incremental Time $(t)$ & Cumulative time $(\Sigma t)$ \\
\hline 1 & 2 hours $\pm 5 \%$ & 2 hours \\
\hline 2 & 5 hours $\pm 5 \%$ & 7 hours \\
\hline 3 & 17 hours $\pm 2 \%$ & 1 day \\
\hline 4 & 1 day $\pm 2 \%$ & 2 days \\
\hline 5 & 1 day $\pm 2 \%$ & 3 days \\
\hline 6 & 1 day $\pm 2 \%$ & 4 days \\
\hline 7 & 1 day $\pm 2 \%$ & 5 days \\
\hline 8 & 1 day $\pm 2 \%$ & 6 days \\
\hline 9 & 1 day $\pm 2 \%$ & 7 days \\
\hline 10 & 1 day $\pm 2 \%$ & 8 days \\
\hline 11 & 1 day $\pm 2 \%$ & 9 days \\
\hline 12 & 1 day $\pm 2 \%$ & 10 days \\
\hline 13 & 1 day $\pm 2 \%$ & 11 days \\
\hline
\end{tabular}

\subsection{Leach Test Results}

Results of the $\mathrm{Na}$ analysis were input to the ALT computer program which performed calculations to determine the Cumulative Fraction Leached (CFL), the Incremental Fraction Leached (IFL), the diffusion coefficient that best fits the leaching data and a value that described the goodness-of-fit between the data and model results. This value is the sum of the differences between the experimental data and the model curve. Goodness-of-fit values that are greater than 100 are excluded from the calculation of average CFLs since these data do not fit the model. Values that are below about 50 are considered to represent a good fit between the data and the 
model and therefore indicate that diffusion is the leaching mecharism. Those between 50 and 100 represent a lesser, but acceptable fit to the diffusion model. Leaching results for each of the temperatures examined are discussed below.

\section{Samples Tested at $20^{\circ} \mathrm{C}$ :}

The data for samples tested at $20^{\circ} \mathrm{C}$ are shown in Table 3.2 and Figures $3.2-3.4$ for waste forms having salt loadings of 50,60, and $70 \mathrm{wt} \%$. Diffusion coefficients range from $8.84 \times 10^{-10}$ $\mathrm{cm}^{2} / \mathrm{s}$ to $6.6 \times 10^{-8} \mathrm{~cm}^{2} / \mathrm{s}$ and CFLs range from 9.6 to $57.3 \%$. Average CFLs were $15.5 \%, 32.2 \%$, and $52.4 \%$ for 50,60 and $70 \mathrm{wt} \%$ samples, respectively. The goodness-of-fit of the data to the diffusion model samples leached at $20^{\circ} \mathrm{C}$ was generally good. Only one sample did not meet the goodness-of-fit criteria of less than 100 , indicating that diffusion does control releases for most samples.

\section{Samples Tested at $35^{\circ} \mathrm{C}$ :}

Data for samples leached at $35^{\circ} \mathrm{C}$ are shown in Table 3.3 and Figures 3.5-3.7. Diffusion coefficients range from $1.12 \times 10^{-9} \mathrm{~cm}^{2} / \mathrm{s}$ to $1.33 \times 10^{-7} \mathrm{~cm}^{2} / \mathrm{s}$ while $\mathrm{CFL}$ values range from $10.9 \%$ to $75.1 \%$.Average CFLs were $14.4 \%, 32.2 \%$, and $58.0 \%$ for 50,60 , and $70 \mathrm{wt} \%$ samples, respectively. The goodness-of-tit for all samples indicates that diffusion is the release mechanism for this group of samples. Samples $60 \% \mathrm{~B}$ and $70 \% \mathrm{~B}$ both have anomalously high CFL values, and sample $60 \% \mathrm{~B}$ is close to the limit for goodness-of-fit.

\section{Samples Leached at $50^{\circ} \mathrm{C}$ :}

Table 3.4 contains results for samples leached at $50^{\circ} \mathrm{C}$ as do Figures $3.8-3.10$. This set of data shows more scatter than the samples leached at lower temperatures. Diffusion coefficients range from $1.37 \times 10^{-9} \mathrm{~cm}^{2} / \mathrm{s}$ to $1.69 \times 10^{-7} \mathrm{~cm}^{2} / \mathrm{s}$ but both extremes are in the same set of replicates. Values of CFL vary from $12.5 \%$ to $90.6 \%$. Average CFLs were $37.5 \%, 35.8 \%$, and $80.7 \%$ for 50 , 
60 , and $70 \mathrm{wt} \%$ samples, respectively. Goodness-of-fit generally indicates that diffusion is the release mechanism. Examination of the leaching curves shows that samples $50 \% \mathrm{C}$ and $70 \% \mathrm{~A}$ are the two that clearly do not fit the model.

\section{Samples Leached at $70^{\circ} \%$ :}

Data for samples leached at $70^{\circ} \mathrm{C}$ are presented in Table 3.5 and Figures $3.11-3.13$. The CFL range from $23.4 \%$ to $97.7 \%$, with diffusion coefficients ranging from $6.78 \times 10^{-9}$ to $3.60 \times 10^{-7}$ $\mathrm{cm}^{2} / \mathrm{s}$. Average CFLs were $26.5 \%, 66.9 \%$, and $85.2 \%$ for 50,60 , and $70 \mathrm{wt} \%$ samples, respectively. For most samples, the goodness-of-fit indicates thai diffusion is the leaching mechanism with the exception of three samples in the $60 \mathrm{wt} \%$ loading set. Anomalies in this data set arc probably due to poor sealing of the specimen surfaces after cutting to the proper size.

\subsection{Discussion of Leach rest Results}

These experiments quantified the effect of two parameters, waste loading and temperature, on leaching. Several topics are of particular interest:

(1) Is diffusion the leaching mechanism for this material at $20^{\circ} \mathrm{C}$ and if it is, does increasing temperature alter the mechanism?

(2) What is the relationship between salt content and leaching?

(3) Can this information be used to predict releases and to provide information from which a better waste form can be produced?

From the data presented in Tables 3.2 -3.5, the goodness-of-fit of the diffusion model to the experimental data is acceptably close for approximately $85 \%$ of the samples tested. The remaining $15 \%$ leach in a manner that appears to be controlled more by dissolution than by transport out of 
the waste form. This is illustrated in Figure 3.3 showing the leaching curve for Sample D for 60 $w t \%$ salt leached at $20^{\circ} \mathrm{C}$. This set of data is less curved than the model results, crossing the model halfway through the exp zriment. Comparison of the data to the model indicates that releases of Na were slower than predicted during the beginning of the experiment and faster toward the end.

This is true in both cases; when the leach rate is above the average of other samples in the same set and when it is significantly below the average. For these samples, releases are less controlled by the difference in concentration (which drives diffusion) than they are by other processes that control access of the leachant to the salt grains or by the kinetics of dissolution. In either case, the structure of the sample that typically inhibits dissolution is not effective. As discussed in Section 3.2, improperly sealed surfaces following cutting of specimens could account for this behavior.

Since most samples in this study have been shown to leach by diffusion, the ALT computer model was used to project releases for several conditions. Table 3.6 shows the cumulative fraction release attained by waste forms after 300 years using the average diffusion coefficients shown in Tables $3.2-3.5$. A production-scale waste form measuring 2 meters in diameter by 2 meters in height is assumed for this extrapolation. Projected releases range from $3.6 \%-16.8 \%$ of the original source term, with samples containing $50 \mathrm{wt} \%$ salt releasing $\mathrm{Na}$ at approximately one third the rate of the $70 \mathrm{wt} \%$ samples. The lowest leaching values are small, and when they are coupled with radioactive decay of $\mathrm{Sr}-90$ and $\mathrm{Cs}-137$, the fraction of the total source term that is released after 300 years is about $0.014 \%$. Based on effective diffusivities derived in previous leaching experiments, conventional cement grout waste forms are projected to leach about $17 \%$ of the contaminants after only 11 years.[18] Thus, polyethylene waste forms containing maximum nitrate salt loadings can be expected to leach about 25 times slower than cement grout waste forms, while solidifying between 3.5 and 5 times more nitrate salt waste. Polyethylene waste forms leached at lower temperatures $\left(20{ }^{\circ} \mathrm{C}\right.$ to $35^{\circ} \mathrm{C}$ ) could be expected to leach about $3.5 \%$ to $11 \%$ of the original contaminants in 300 years. Thus, reduction in the thermal load due to fission products by removal of some of the Cs-137 and Sr-90 from SST wastes could result in lower leachabilities by a factor of about 2 times. Figure 3.14 shows the relationship of leachability (CFL) as a function of waste loading at four 
temperatures. Examination of leaching data from an earlier study, that extended to lower loadings than the current experiments, indicated that the relationship between salt loading and leaching is an exponential function in which leaching becomes very small as salt loading approaches zero. [5]

The effect of temperature can be seen in Figure 3.15 which is an Arrhenius plot of the natural $\log$ of diffusion coefficients plotted as a function of inverse temperature in kelvins. The slopes are quite low and yield activation energies of $2.5,2.2$, and $2.9 \mathrm{Kcal} / \mathrm{mole}$ for sample containing 50,60 , and $70 \mathrm{wt} \% \mathrm{NaNO}_{3}$ respectively. These values compare quite closely to typical activation energies of $3-5 \mathrm{Kcal} / \mathrm{mole}$ for diffusion. The Arrhenius plot also indicates that the leaching mechanism does not change between $20^{\circ} \mathrm{C}$ and $70^{\circ} \mathrm{C}$ since the slopes of the lines remain unchanged.

\subsection{Conclusions Regarding Waste Form Leaching}

Based on the data presented in this section several conclusions can be drawn. The leaching of a highly soluble salt contained in polyethylene is diffusion controlled. However, exceptions to this can occur when the surfaces of the waste form are disturbed, creating potential preferential pathways for leaching. Because diffusion was shown to be the operative mechanism, projections were made for cumulative fraction releases out to 300 years using diffusion coefficients measured at 4 temperatures and for 3 waste loadings. Compared with conventional cement grout, polyethylene leach rates are 25 to 75 times lower.

Temperature has a sinall effect on leaching, increasing diffusion coefficients by a factor of approximately four over a 50 degree temperature range. Salt loading has a greater influence on leaching, as CFLs approximately double for each $10 \mathrm{wt} \%$ increase in salt loading. The data in this study indicates that while releases from polyethylene/sodium nitrate waste forms are low even at maximum waste loadings (i.e., $70 \mathrm{wt} \%$ ), leach rates can be reduced by a factor of 3 to 4 times by reducing nitrate salt loadings to $50 \mathrm{wt} \%$. 
Table 3.2. Accelerated Leach Test Results Conducted at $20^{\circ} \mathrm{C}$ for $\mathrm{NaNO}_{3}$ Encapsulated in Polyethylene

\begin{tabular}{|c|c|c|c|}
\hline SAMPLE & $\begin{array}{l}\text { CUMULATIVE } \\
\text { FRACTION } \\
\text { LEACHED (\%) }\end{array}$ & $\begin{array}{l}\text { DIFFUSION } \\
\text { COEFFICIENT } \\
\left(\mathrm{cm}^{2} / \mathrm{sec}\right)\end{array}$ & GOODNESS-OF-FIT \\
\hline \multicolumn{4}{|l|}{$50 \% \mathrm{NaNO}_{3}$} \\
\hline A & 14.8 & $2.32 \times 10^{-9}$ & 3.7 \\
\hline $\mathrm{B}$ & 18.9 & $4.67 \times 10^{-9}$ & 8.13 \\
\hline $\mathrm{C}$ & 18.5 & $4.37 \times 10^{-9}$ & 5.0 \\
\hline D & 9.6 & $8.84 \times 10^{-10}$ & 24.2 \\
\hline A.VERAGE & 15.5 & $3.05 \times 10^{-9}$ & 10.3 \\
\hline \multicolumn{4}{|l|}{$60 \% \mathrm{NaNO}_{3}$} \\
\hline A & 25.3 & $8.45 \times 10^{-9}$ & 2.02 \\
\hline B & 34.0 & $1.63 \times 10^{-8}$ & 27.5 \\
\hline c & 10.7 & $1.17 \times 10^{-9}$ & 15.7 \\
\hline D & 58.8 & $6.21 \times 10^{-8}$ & $184.0 *$ \\
\hline AVERAGE & 32.2 & $2.2 \times 10^{-8}$ & 15.1 \\
\hline \multicolumn{4}{|l|}{$70 \% \mathrm{NaNO}_{3}$} \\
\hline $\mathbf{A}$ & 50.2 & $4.78 \times 10^{-8}$ & 20.6 \\
\hline $\mathrm{B}$ & 54.4 & $6.10 \times 10^{-8}$ & 21.2 \\
\hline $\mathrm{C}$ & 47.6 & $482 \times 10^{-8}$ & 43.8 \\
\hline $\mathbf{D}$ & 57.3 & $6.60 \times 10^{-8}$ & 44.1 \\
\hline AVERAGE & 52.4 & $5.58 \times 10^{-8}$ & 32.4 \\
\hline
\end{tabular}

*Not included in average. 
Table 3.3 Accelerated Leach Test Results Conducted at $35^{\circ} \mathrm{C}$ for $\mathrm{NaNO}_{3}$ Encapsulated in Polyethylene

\begin{tabular}{|c|c|c|c|}
\hline SAMPLE & $\begin{array}{l}\text { CUMULATIVE } \\
\text { FRACTION } \\
\text { LEACHED (\%) }\end{array}$ & $\begin{array}{l}\text { DIFFUSION } \\
\text { COEFFICIENT } \\
\left(\mathrm{cm}^{2} / \mathrm{sec}\right)\end{array}$ & GOODNESS-OF-FIT \\
\hline \multicolumn{4}{|l|}{$50 \% \mathrm{NaNO}_{3}$} \\
\hline A & 17.6 & $3.85 \times 10^{-9}$ & 3.17 \\
\hline B & 18.1 & $4.50 \times 10^{-9}$ & 5.61 \\
\hline $\mathrm{C}$ & 11.1 & $1.14 \times 10^{-5}$ & 6.33 \\
\hline D & 10.9 & $1.12 \times 10^{-9}$ & 2.83 \\
\hline AVERAGE & 14.4 & $2.65 \times 10^{-9}$ & 4.49 \\
\hline \multicolumn{4}{|l|}{$60 \% \mathrm{NaNO}_{3}$} \\
\hline A & 22.3 & $7.10 \times 10^{-9}$ & 1.56 \\
\hline B & 50.5 & $4.65 \times 10^{-8}$ & 70.70 \\
\hline $\mathrm{C}$ & 30.0 & $1.26 \times 10^{-8}$ & 0.60 \\
\hline D & 25.1 & $9.82 \times 10^{-9}$ & 15.10 \\
\hline AVERAGE & 32.0 & $1.90 \times 10^{-8}$ & 22.00 \\
\hline & & 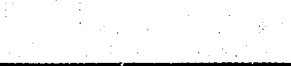 & \\
\hline \multicolumn{4}{|l|}{$70 \% \mathrm{NaNO}_{3}$} \\
\hline A & 53.0 & $5.67 \times 10^{-8}$ & 3.18 \\
\hline B & 75.1 & $1.33 \times 10^{-7}$ & 19.50 \\
\hline $\mathrm{C}$ & 57.7 & $6.75 \times 10^{-8}$ & 26.00 \\
\hline D & 46.2 & $4.79 \times 10^{-8}$ & 43.90 \\
\hline AVERAGE & 58.0 & $7.63 \times 10^{-8}$ & 23.10 \\
\hline
\end{tabular}


Table 3.4. Accelerated Leach Test Results Conducted at $50^{\circ} \mathrm{C}$ for $\mathrm{NaNO}_{3}$ Encapsulated in Polyethylene

\begin{tabular}{|c|c|c|c|}
\hline SAMPLE & $\begin{array}{c}\text { CUMULATIVE } \\
\text { FRACTION } \\
\text { LEACHED } \\
(\%)\end{array}$ & $\begin{array}{c}\text { DIFFUSION } \\
\text { COEFFICIENT } \\
\left(\mathrm{cm}^{2} / \mathrm{sec}\right)\end{array}$ & GOODNESS-OF-FIT \\
\hline \multicolumn{4}{|l|}{$50 \% \mathrm{NaNO}_{3}$} \\
\hline A & 20.1 & $4.93 \times 10^{-9}$ & 7.64 \\
\hline B & 12.5 & $1.37 \times 10^{-9}$ & 77.1 \\
\hline $\mathrm{C}$ & 90.6 & $1.69 \times 10^{-7}$ & $942 *$ \\
\hline $\mathrm{D}$ & 26.7 & $9.69 \times 10^{-9}$ & 3.20 \\
\hline AVERAGE & 37.5 & $4.62 \times 10^{-8}$ & 29.3 \\
\hline \multicolumn{4}{|l|}{$60 \% \mathrm{NaNO}_{3}$} \\
\hline A & 23.8 & $7.70 \times 10^{-9}$ & 1.19 \\
\hline B & 55.4 & $5.83 \times 10^{-8}$ & 46.0 \\
\hline $\mathrm{C}$ & 10.4 & $9.90 \times 10^{-10}$ & 15.3 \\
\hline $\mathrm{D}$ & 53.5 & $5.70 \times 10^{-8}$ & 5.35 \\
\hline AVERAGE & 35.8 & $3.10 \times 10^{-8}$ & 17.0 \\
\hline \multicolumn{4}{|l|}{$70 \% \mathrm{NANO}_{3}$} \\
\hline A & 90.4 & $2.47 \times 10^{-7}$ & $136 *$ \\
\hline B & 77.1 & $1.43 \times 10^{-7}$ & 41.6 \\
\hline $\mathrm{C}$ & 75.3 & $1.24 \times 10^{-7}$ & 61.0 \\
\hline D & 80.1 & $1.44 \times 10^{-7}$ & $120 *$ \\
\hline AVERAGE & 80.7 & $1.64 \times 10^{-7}$ & 51.3 \\
\hline
\end{tabular}

*Not included in average. 
Table 3.5 Accelerated Leach Test Results Conducted at $70^{\circ} \mathrm{C}$ for $\mathrm{NaNO}_{3}$ Encapsulated in Polyethylene

\begin{tabular}{|c|c|c|c|}
\hline SAMPLE & $\begin{array}{c}\text { CUMULATIVE } \\
\text { FRACTION } \\
\text { LEACHED } \\
(\%)\end{array}$ & $\begin{array}{l}\text { DIFFUSION } \\
\text { COEFFICIENT } \\
\left(\mathrm{cm}^{2} / \mathrm{sec}\right)\end{array}$ & GOODNESS-OF-FIT \\
\hline \multicolumn{4}{|l|}{$50 \% \mathrm{NaNO}_{3}$} \\
\hline A & 27.5 & $1.06 \times 10^{-8}$ & 10.2 \\
\hline B & 25.7 & $9.10 \times 10^{-9}$ & 4.11 \\
\hline $\mathrm{C}$ & 29.4 & $7.23 \times 10^{-8}$ & 0.88 \\
\hline $\mathrm{D}$ & 23.4 & $6.78 \times 10^{-9}$ & 1.87 \\
\hline AVERAGE & 26.5 & $9.69 \times 10^{-9}$ & 4.26 \\
\hline \multicolumn{4}{|l|}{$60 \% \mathrm{NaNO}_{3}$} \\
\hline A & 38.6 & $2.40 \times 10^{-8}$ & 10.4 \\
\hline B & 81.6 & $1.39 \times 10^{-7}$ & $374 *$ \\
\hline $\mathrm{C}$ & 89.7 & $1.85 \times 10^{-7}$ & $577^{*}$ \\
\hline $\mathrm{D}$ & 57.5 & $5.77 \times 10^{-8}$ & $148^{*}$ \\
\hline AVERAGE & 66.9 & $1.01 \times 10^{-7}$ & - \\
\hline \multicolumn{4}{|l|}{$70 \% \mathrm{NaNO}_{3}$} \\
\hline $\mathrm{A}$ & 97.7 & $3.60 \times 10^{-7}$ & 97.7 \\
\hline B & 67.7 & $8.93 \times 10^{-8}$ & 54.8 \\
\hline $\mathrm{C}$ & 92.7 & $2.99 \times 10^{-7}$ & 36.2 \\
\hline D & 82.7 & $1.83 \times 10^{-7}$ & 33.1 \\
\hline AVERAGE & 85.2 & $2.33 \times 10^{-7}$ & 55.5 \\
\hline
\end{tabular}

*Not included in average. 
Table 3.6 Projected Cumulative Fractional Releases After 300 Years of Leaching for Full-Scale Polyethylene Waste Forms Containing Nitrate Salt Wastes

\begin{tabular}{|c|c|c|c|c|c|c|}
\hline \multirow{3}{*}{$\begin{array}{c}\text { Temperature } \\
{ }^{\circ} \mathrm{C}\end{array}$} & \multicolumn{4}{|c|}{ Projected Releases } & & \\
\hline & \multicolumn{2}{|c|}{$50 \mathrm{wt} \%$ Salt } & \multicolumn{2}{|c|}{60 wt \% Salt } & \multicolumn{2}{|c|}{70 wt\% Salt } \\
\hline & $D_{c}\left(\mathrm{~cm}^{2} / \mathrm{s}\right)$ & CFL (\%) & $D_{0}\left(\mathrm{~cm}^{2} / \mathrm{s}\right)$ & CFL (\%) & $D_{c}\left(\mathrm{~cm}^{2} / \mathrm{s}\right)$ & CFL (\%) \\
\hline 20 & $3.05 \times 10^{-9}$ & 3.7 & $8.6 \times 10^{-9}$ & 5.0 & $5.58 \times 10^{-8}$ & 9.5 \\
\hline 35 & $2.65 \times 10^{-9}$ & 3.6 & $1.90 \times 10^{-8}$ & 6.3 & $7.63 \times 10^{-8}$ & 10.7 \\
\hline 50 & $5.32 \times 10^{-9}$ & 4.3 & $3.10 \times 10^{-8}$ & 7.6 & $1.34 \times 10^{-7}$ & 13.4 \\
\hline 70 & $9.69 \times 10^{-9}$ & 5.1 & $2.40 \times 10^{-8}$ & 6.9 & $2.33 \times 10^{-7}$ & 16.8 \\
\hline
\end{tabular}

a) Projected releases for 6.3 cubic meter full-scale waste form ( $2 \mathrm{~m}$ diameter $\times 2 \mathrm{~m}$ in height). 


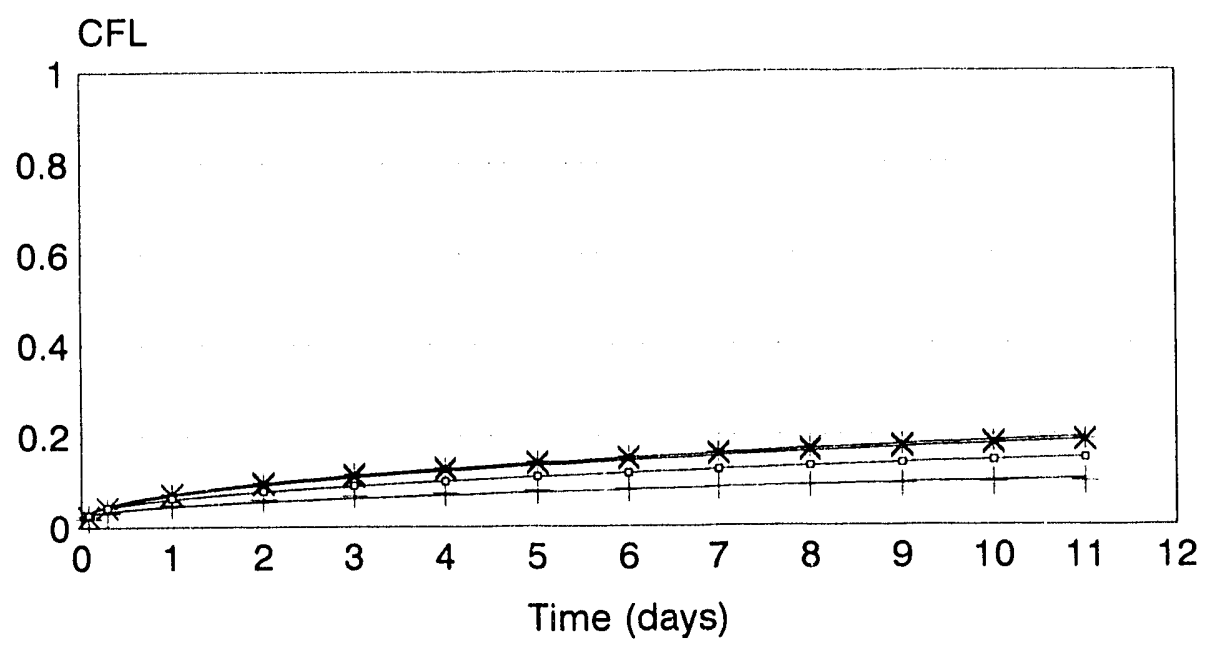

- Sample A $*$ Sample B $\times$ Sample C + Sample D

Figure 3.2 Accelerated Leach Test results for polyethylene waste forms with sodium nitrate salt loadings of $50 \mathrm{wt} \%$ tested at $20^{\circ} \mathrm{C}$.

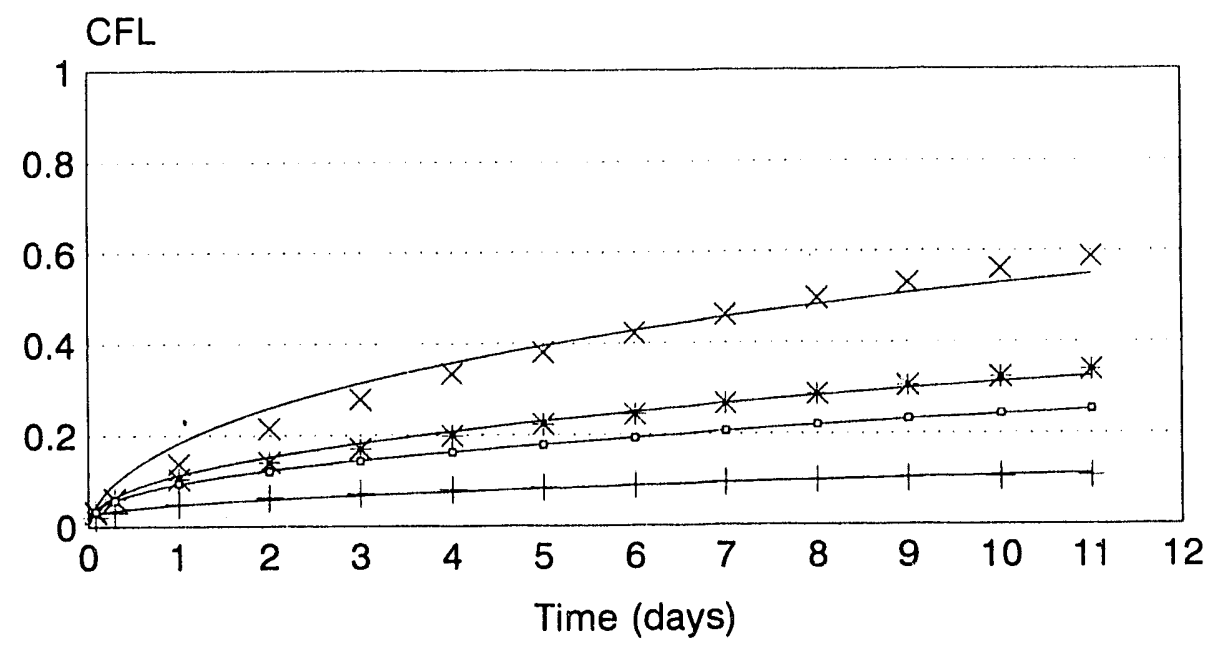

- Sample A * Sample B + Sample C × Sample D

Figure 3.3 Accelerated Leach Test results for polyethylene waste forms with sodium nitrate salt loadings of $60 \mathrm{wt} \%$ tested at $20^{\circ} \mathrm{C}$. 


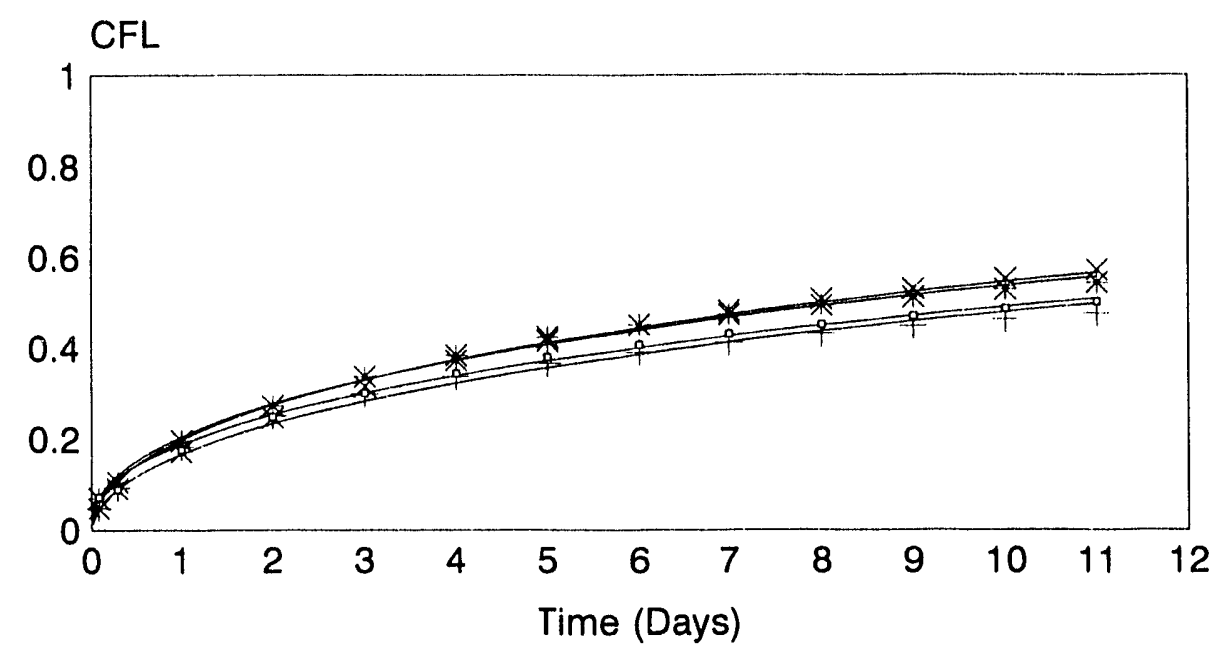

- Sample A * Sample B $\times$ Sample C + Sample D

Figure 3.4 Accelerated Leach Test results for polyethylene waste forms with sodium nitrate salt loadings of $70 \mathrm{wt} \%$ tested at $20^{\circ} \mathrm{C}$.

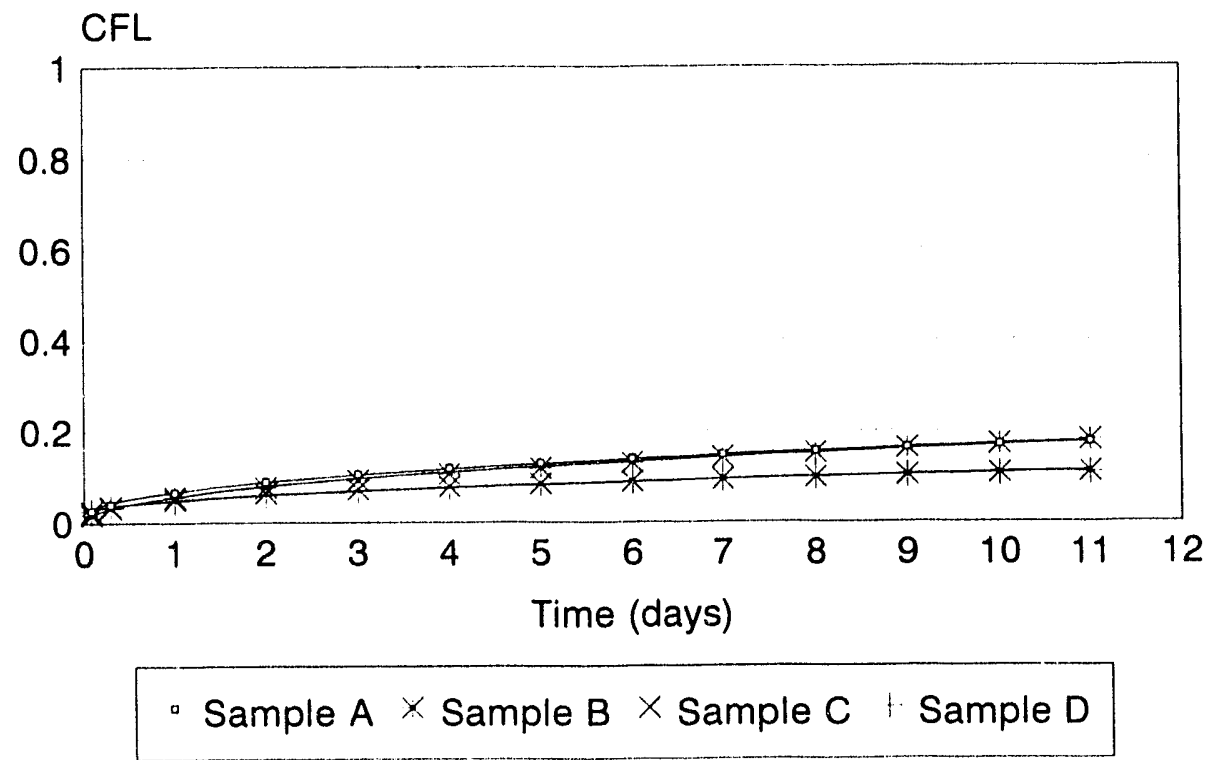

Figure 3.5 Accelerated Leach Test results for polyethylene waste forms with sodium nitrate salt loadings of $50 \mathrm{wt} \%$ tested at $35^{\circ} \mathrm{C}$. 


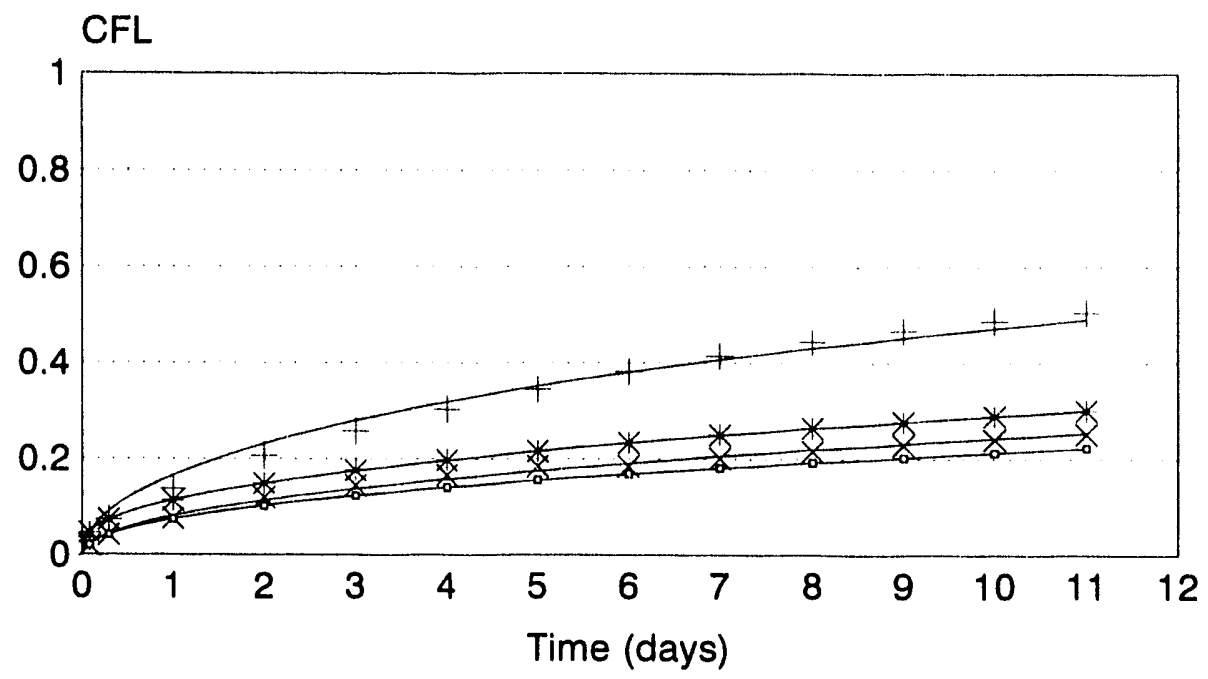

- Sample A + Sample B * Sample C × Sample D

Figure 3.6 Accelerated Leach Test results for polyethylene waste forms with sodium nitrate salt loadings of $60 \mathrm{wt} \%$ tested at $35^{\circ} \mathrm{C}$.

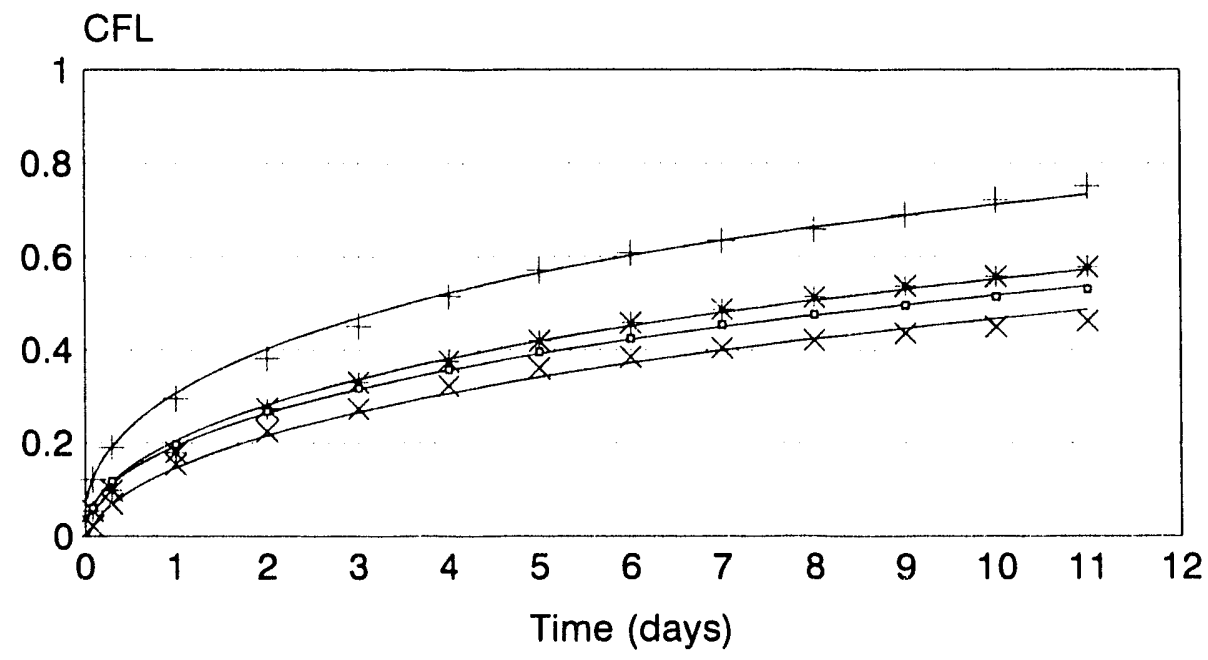

- Sample A + Sample B $*$ Sample C $\times$ Sample D

Figure 3.7 Accelerated Leach Test results for polyethylene waste forms with sodium nitrate salt loadings of $70 \mathrm{wt} \%$ tested at $35^{\circ} \mathrm{C}$. 


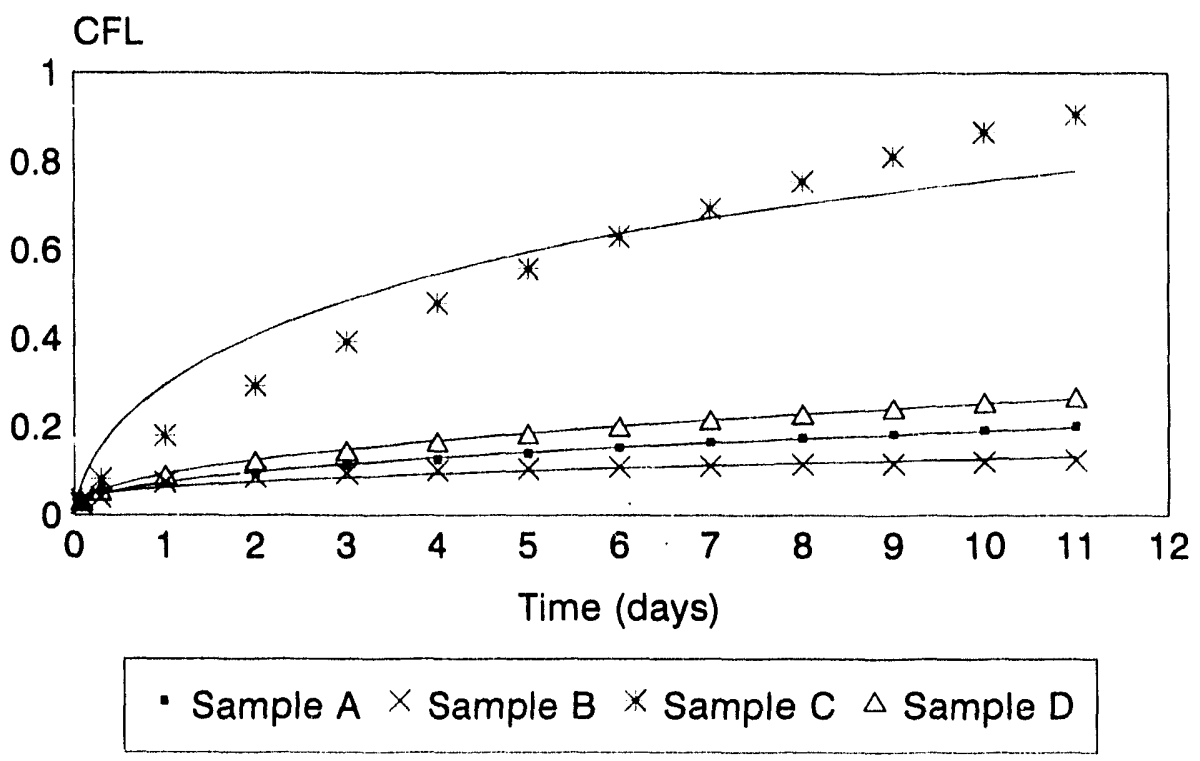

Figure 3.8 Accelerated Leach Test results for polyethylene waste forms with sodium nitrate salt loadings of $50 \mathrm{wt} \%$ tested at $50^{\circ} \mathrm{C}$.

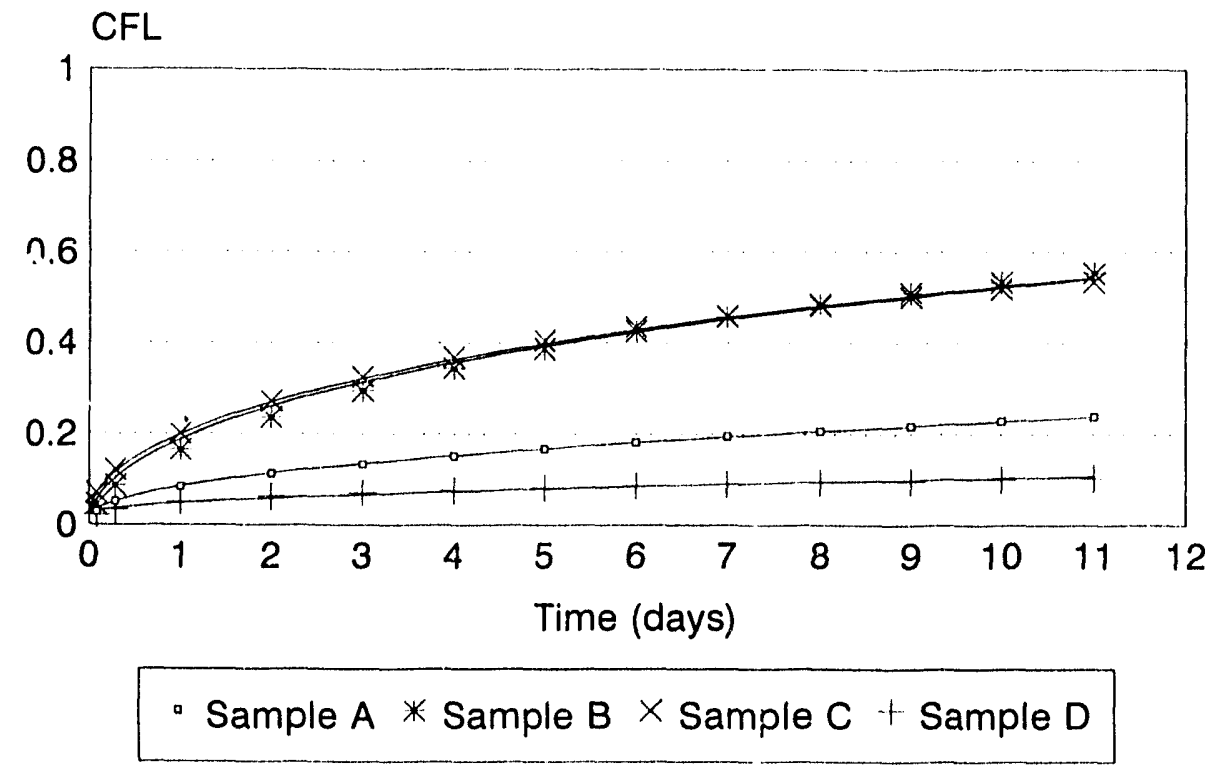

Figure 3.9 Accelerated Leach Test results for polyethylene waste forms with sodium nitrate salt loadings of $60 \mathrm{wt} \%$ tested at $50^{\circ} \mathrm{C}$. 


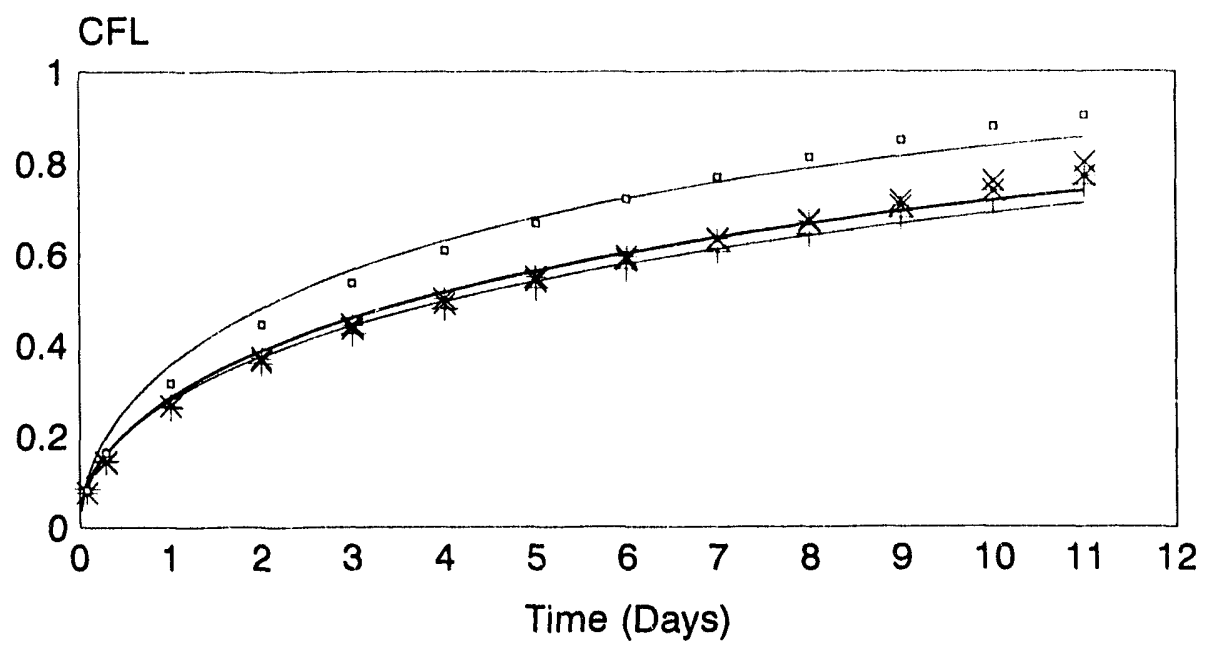

- Sample A $*$ Sample B $\times$ Sample C + Sample D

Figure 3.10 Accelerated Leach Test results for polyethylene waste forms with sodium nitrate salt loadings of $70 \mathrm{wt} \%$ tested at $50^{\circ} \mathrm{C}$.

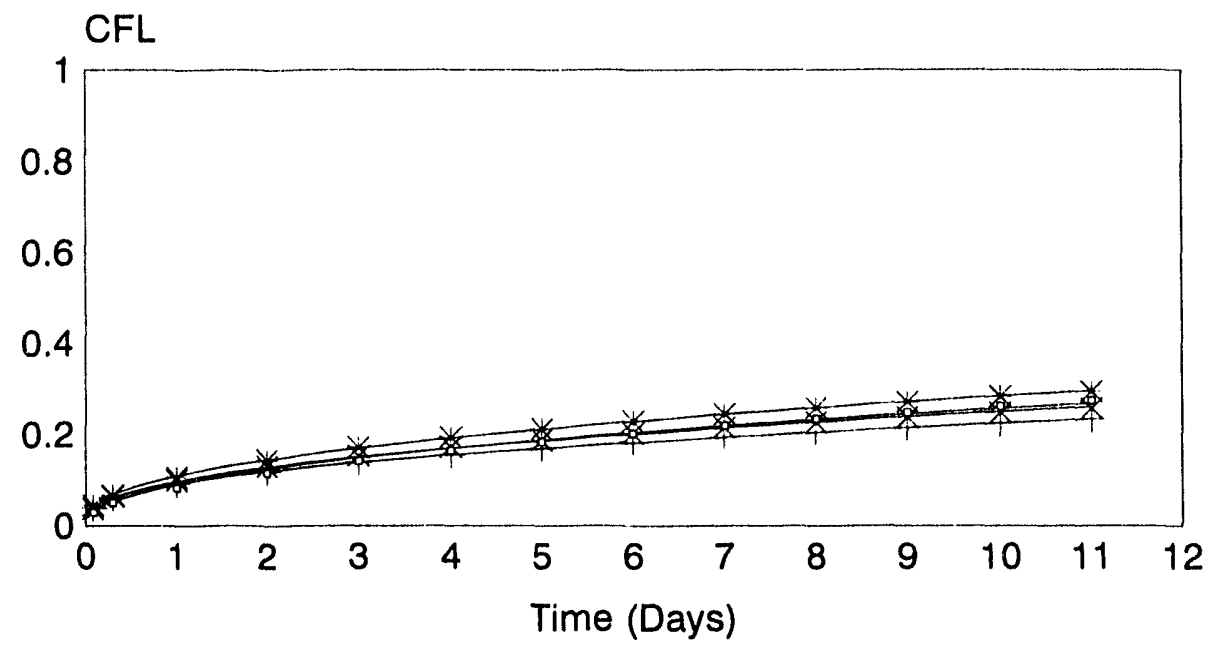

- Sample A * Sample B $\times$ Sample C + Sample D

Figure 3.11 Accelerated Leach Test results for polyethylene waste forms with sodium nitrate salt loadings of $50 \mathrm{wt} \%$ tested at $70^{\circ} \mathrm{C}$. 


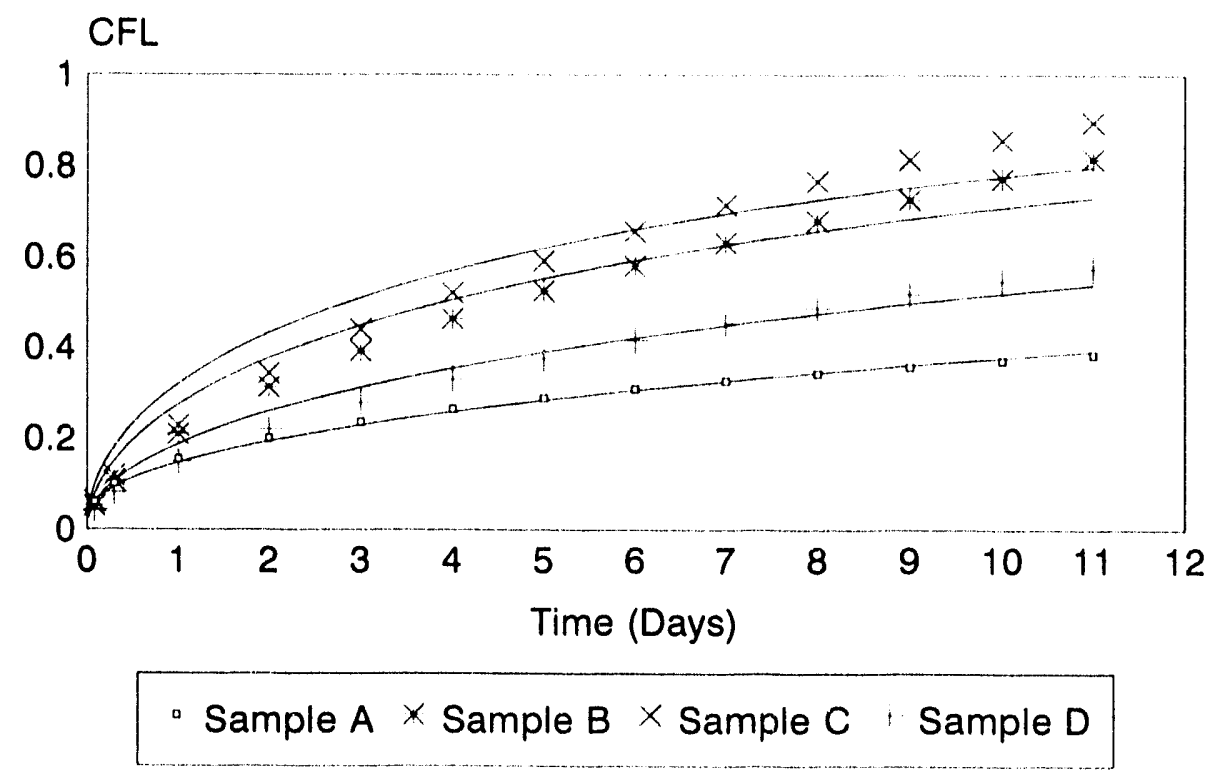

Figure 3.12 Accelerated Leach Test results for polyethylene waste forms with sodium nitrate salt loadings of $60 \mathrm{wt} \%$ tested at $70^{\circ} \mathrm{C}$.

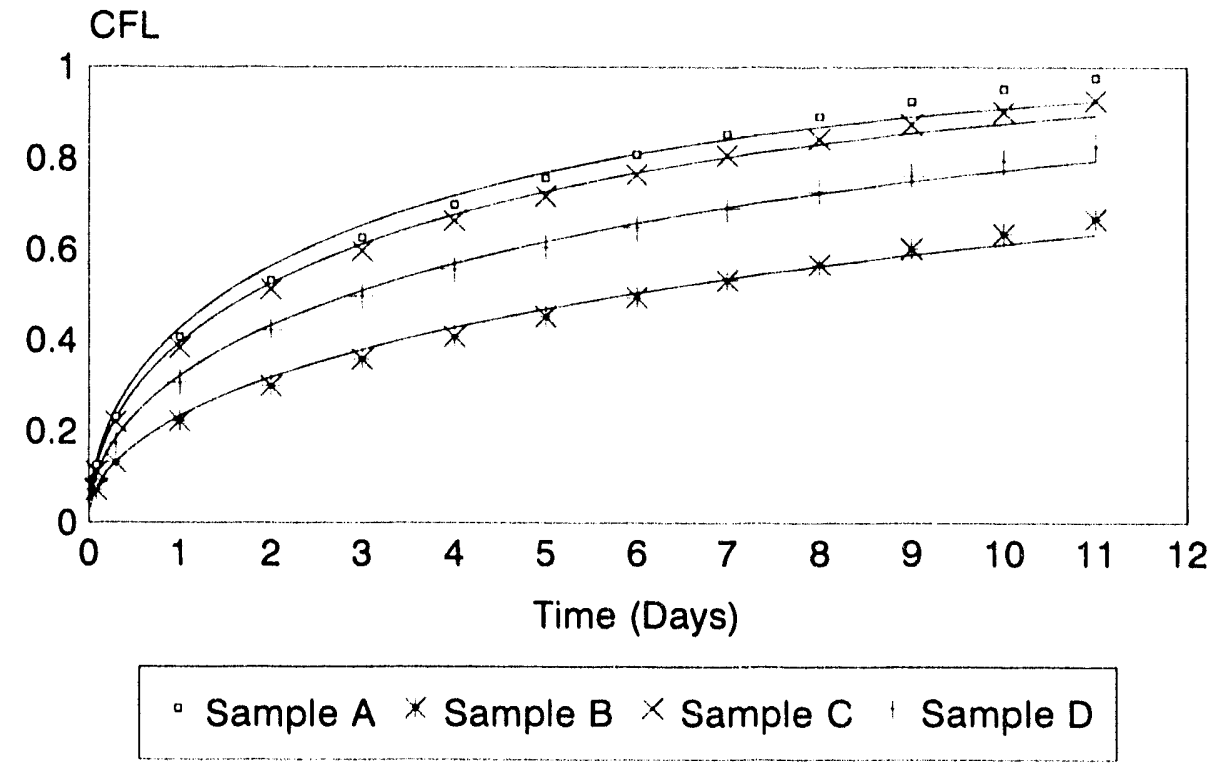

Figure 3.13 iccelerated Leach Test results for polyethylene waste forms with sodium nitrate salt loadings of $70 \mathrm{wt} \%$ tested at $70^{\circ} \mathrm{C}$. 


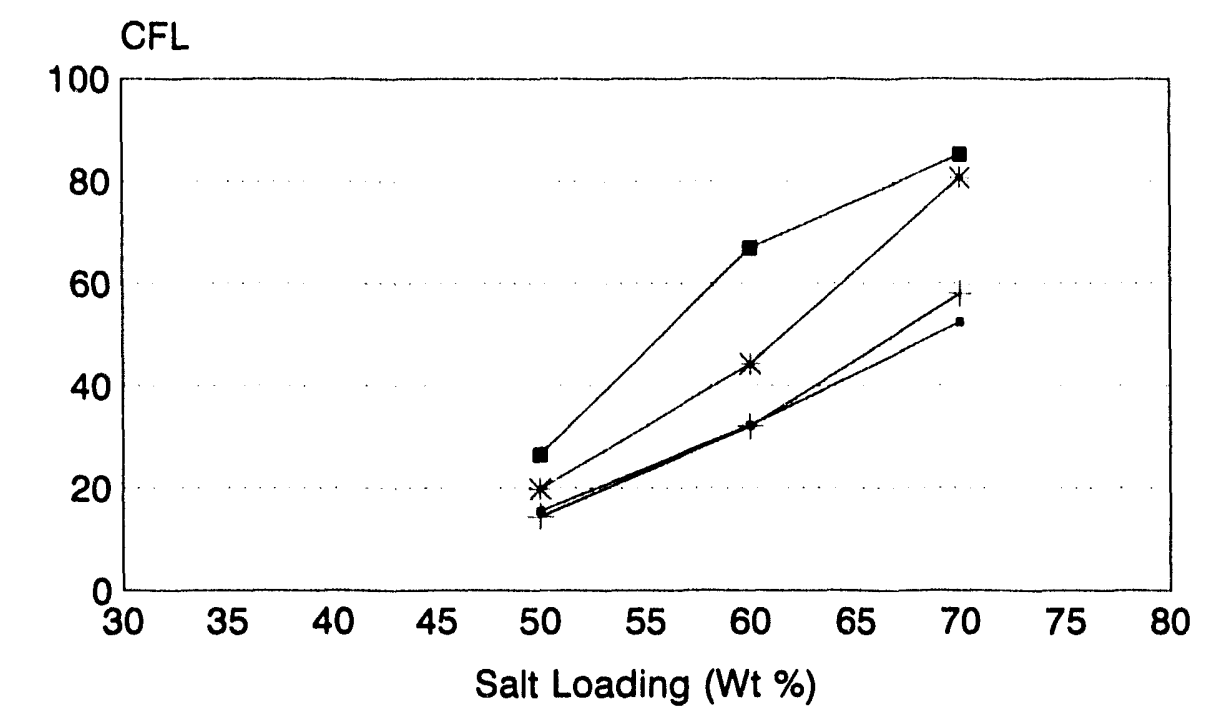

\section{$\rightarrow$ CFL at $20 \mathrm{C}+\mathrm{CFL}$ at $35 \mathrm{C} \quad$ * CFL at $50 \mathrm{C}-\mathrm{CFL}$ at $70 \mathrm{C}$}

Figure 3.14 Relationship of leachability (CFL) as a function of waste loading at $20^{\circ} \mathrm{C}, 35^{\circ} \mathrm{C}$, $50^{\circ} \mathrm{C}$, and $70^{\circ} \mathrm{C}$.

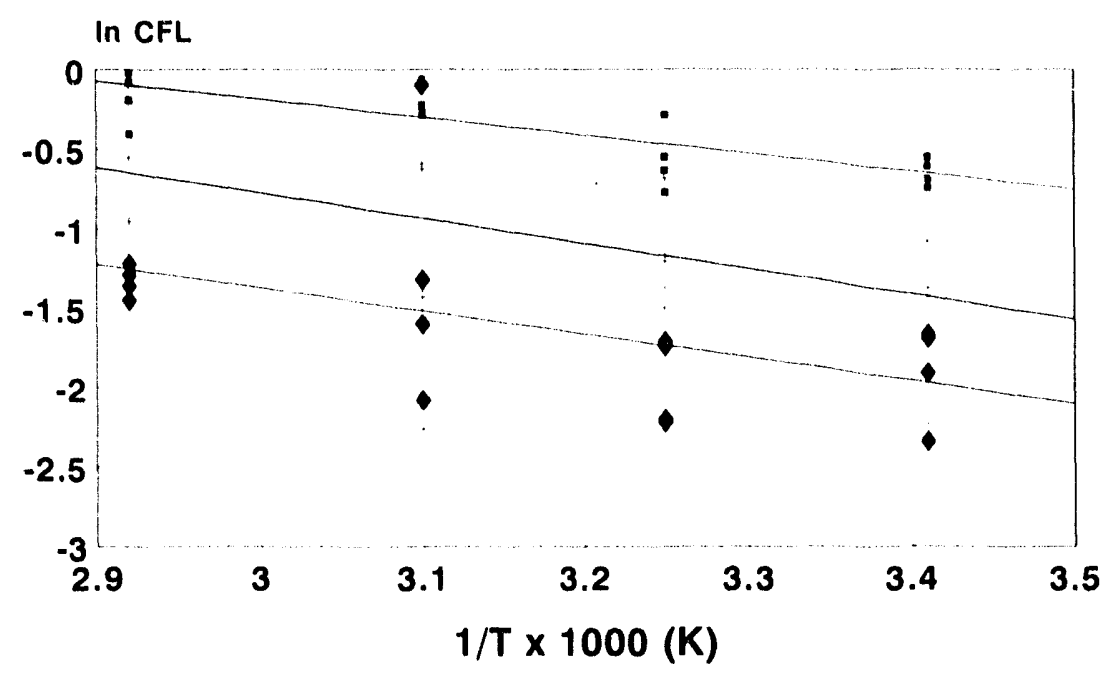

- In $70 \%$ salt - In $60 \%$ salt + In $50 \%$ salt

Figure 3.15 Arrhenius plot of the natural log of diffusion coefficients for polyethylene waste forms containing sodium nitrate plotted as a function of inverse leaching temperature in kelvins. 


\section{THERMAL EFFECTS ON WASTE FORM STRENGTH AND INTEGRITY}

Since polyethylene has a melting point of $120^{\circ} \mathrm{C}$ and the anticipated equilibrium temperature of the SST waste is $50-70^{\circ} \mathrm{C}$, the stability of polyethylene waste forms under these conditions was an issue raised by the UST-ID. In response, this test was conducted to examine the effects of elevated temperatures on the physical integrity and strength properties of polyethylene waste forms containing simulated sodium nitrate waste.

Simulated waste form specimens containing sodium nitrate at 50,60, and $70 \mathrm{wt} \%$ waste loadings were fabricated using the BNL bench-scale extruder and prepared for testing as described in Section 2.3. 15 replicate specimens at each waste loading were thermally conditioned at each temperature $\left(50\right.$ and $\left.70^{\circ} \mathrm{C}\right)$ for a total of 90 specimens. Specimens were weighed and measured prior to thermal conditioning.

The two thermal test chambers (Cole Parmer Instruments) are microprocessor controlled with RTD sensors, and digital display of actual and set temperatures. Heat transfer is by convection, regulated by a variable speed air-circulating fan. Temperature stability specifications are $\pm 0.5^{\circ} \mathrm{C}$ at $100^{\circ} \mathrm{C}$. Thermocouples were installed inside the chambers and in the center of several waste forms to monitor temperatures over the course of the experiment. A data acquisition system was used to log temperatures.

After three months of conditioning at $50^{\circ} \mathrm{C}$ and $70^{\circ} \mathrm{C}, 5$ replicates of each waste loading (a total of 30 specimens) were removed from the chambers and allowed to equilibrate to ambient temperature. The remaining specimens were left in the chambers to examine the effects of elevated temperatures for longer times. Following thermal conditioning, specimens were weighed and measured again to check for changes in mass or dimensions resulting from storage at elevated temperatures. Data are included in the Appendix. Changes in weight were very slight - the maximum weight gain or loss was $0.05 \%$. Slight changes in physical dimensions were recorded resulting in volume changes up to about $2.5 \%$, but these variations are within the limits of normal measurement error. 
Polyethylene Encapsulation of SST LLW Annual Report

Thermally conditioned specimens were then tested for changes in mechanical strength according to ASTM Method D-695, "Standard Method of Test for Compressive Properties of Rigid Plastics." Since polyethylene specimens do not always fail catastrophically, stress was plotted as a function of time. Compressive yield strength was determined at the point where the slope decreased to zero. A typical plot of compressive stress vs. time is shown in Figure 4.1. The remaining plots are included in the Appendix. Compressive yield strength for UST-ID polyethylene waste forms containing sodium nitrate stored at elevated and ambient temperatures is presented in Table 4.1 and Figures 4.2 and 4.3. These data represent the average of 5 replicates with the associated error reported at the $95 \%$ confidence limit. Although the percent of original strength ranged from $94 \%$ to $111 \%$, no statistically significant changes in compressive yield strength were observed as a result of thermal conditioning at these anticipated temperatures for periods of 3 months.

Table 4.1 Compressive Yield Strength for UST-ID Polyethylene Waste Forms Containing Sodium Nitrate Stored at Elevated and Ambient Temperatures ${ }^{(\boldsymbol{\alpha})}$

\begin{tabular}{||l|l|l|l|l|l||}
\hline & $\begin{array}{l}\text { Control } \\
\text { (ambient } \\
\text { temperature) }\end{array}$ & \multicolumn{2}{|l|}{ Stored at $50^{\circ} \mathrm{C}, 3$ months } & \multicolumn{2}{l||}{ Stored at $70^{\circ} \mathrm{C}, 3$ months } \\
\hline $\begin{array}{l}\text { Waste } \\
\text { Loading, } \\
\text { wt\% }\end{array}$ & $\begin{array}{l}\text { Yield } \\
\text { Strength, psi }\end{array}$ & $\begin{array}{l}\text { Yield } \\
\text { Strength, psi }\end{array}$ & $\begin{array}{l}\text { \% of } \\
\text { Original } \\
\text { Strength }\end{array}$ & $\begin{array}{l}\text { Yield } \\
\text { Strength, psi }\end{array}$ & $\begin{array}{l}\text { \% of } \\
\text { Original } \\
\text { Strength }\end{array}$ \\
\hline 50 & $2080 \pm 260$ & $2010 \pm 280$ & 96.6 & $1960 \pm 130$ & 94.2 \\
\hline 60 & $1600 \pm 140$ & $1730 \pm 150$ & 108.1 & $1780 \pm 200$ & 111.3 \\
\hline 70 & $1500 \pm 200$ & $1570 \pm 200$ & 104.7 & $1580 \pm 200$ & 105.3 \\
\hline
\end{tabular}

a) Average of 5 replicates. Error calculated at $95 \%$ confidence limit.

Preliminary results after 3 months of storage at $50^{\circ} \mathrm{C}$ and $70^{\circ} \mathrm{C}$ indicate that the mechanical integrity and strength of polyethylene waste forms containing sodium nitrate would not be affected by anticipated thermal loads associated with SST wastes. Further work planned for FY 1993 will examine potential effects at longer times, elevated temperature creep behavior, and possible synergistic effects of high radiation dose and temperature. 


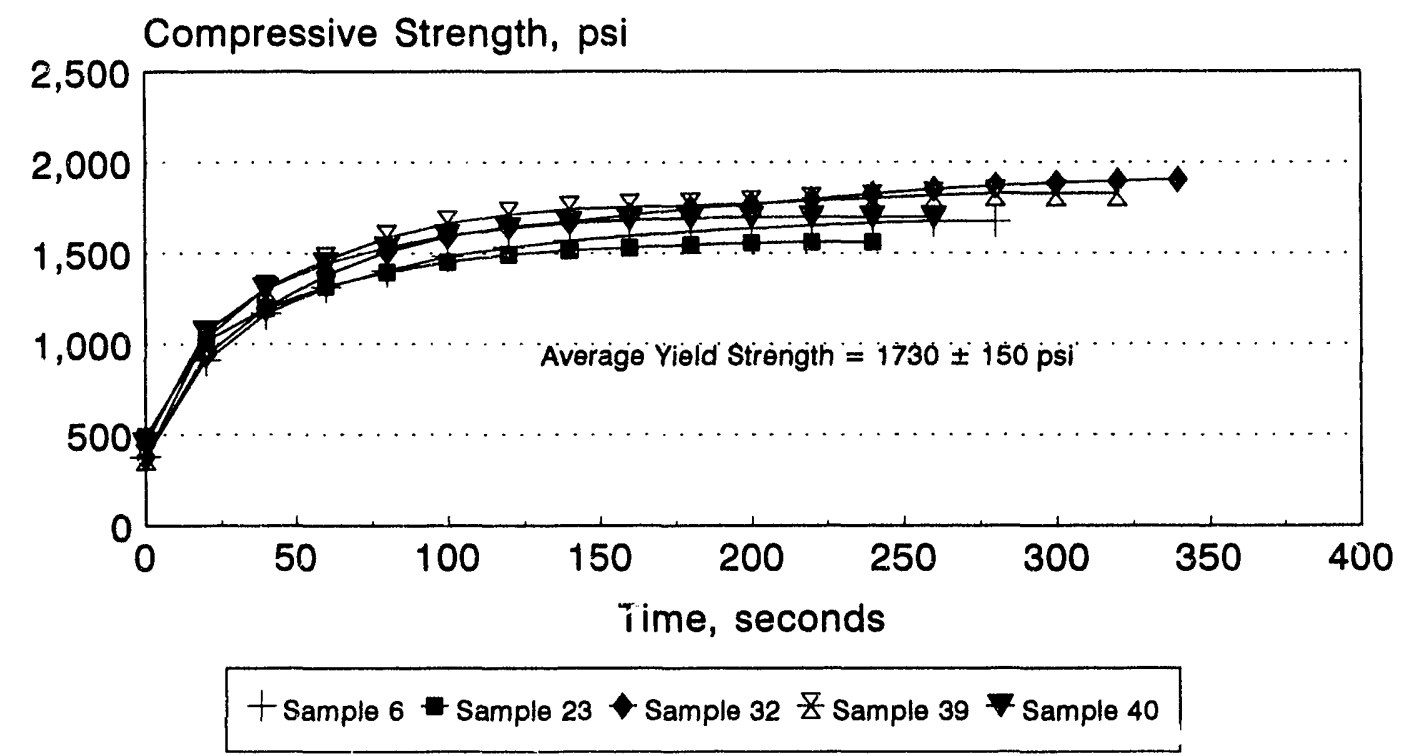

Figure 4.1 Typical compressive yield stress data plotted as a function of time for 5 replicate polyethylene waste form specimens containing sodium nitrate (60 wt\% $\mathrm{NaNO}_{3}$, stored at $50^{\circ} \mathrm{C}$ for 3 months).

\section{Compressive Yield Strength, psi}

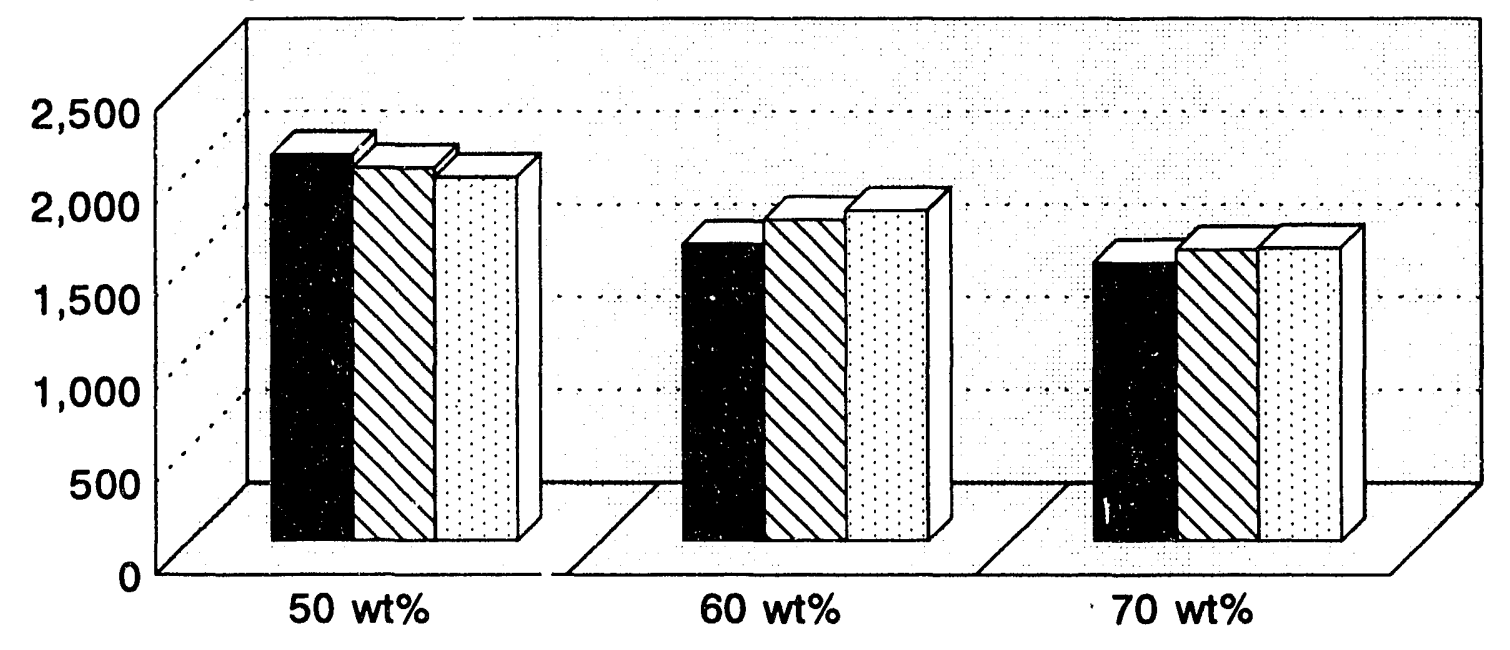

Control Specimens $\triangle 50^{\circ} \mathrm{C}, 3$ months $\square 70^{\circ} \mathrm{C}, 3$ months

Figure 4.2 Compressive yield strength for UST-ID polyethylene waste forms containing sodium nitrate stored at elevated and ambient temperatures. 


\section{Percent of Original Strength}

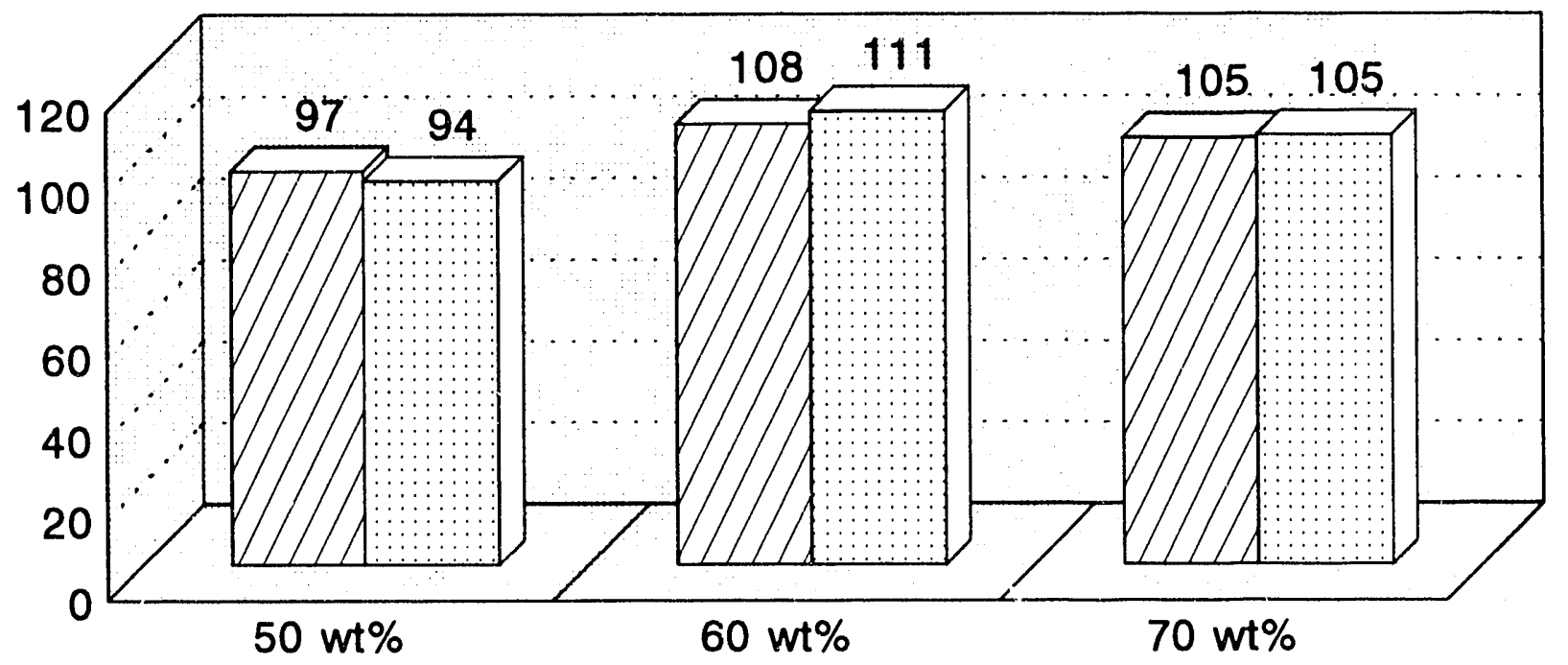

$\square 50^{\circ} \mathrm{C}, 3$ months $\square 70^{\circ} \mathrm{C}, 3$ months

Figure 4.3 Percent of original compressive strength for polyehtylene waste forms containing sodium nitrate. 


\section{SUMMARY AND CONCLUSIONS}

Testing completed in FY 1992 represents an important step toward determining the performance of polyethylene waste forms for SST LLW under anticipated conditions. The information generated as a result of this activity will assist Westinghouse Hanford Co. and the Underground Storage Tank Integrated Demonstration in assessing potential alternatives for improved final waste forms needed to stabilize tank wastes.

Although Phase $I$ of this effort is not yet completed, several significant findings and conclusions can be drawn as a result of the work completed to date:

- The leaching of nitrates and other soluble salts from polyethylene waste forms is diffusion controlled, enabling prediction of releases for full-scale waste forms over long time intervals.

- Full-scale polyethylene waste forms can be expected to leach a total of 5\% to $17 \%$ of the original contaminant source term (for waste forms containing $50 \mathrm{wt} \%$ and $\mathbf{7 0}$ wt\% nitrate salts, respectively) after 300 years of leaching under worst-case $\left(70^{\circ} \mathrm{C}\right.$, fully saturated) conditions.

- Elevated temperatures up to $70^{\circ} \mathrm{C}$ have a negligible impact on polyethylene leachability. Compared with leaching at ambient temperature, projected cumulative fraction releases for full-scale polyethylene waste forms increase by factors of 1.4 to 1.8 for waste forms containing $50 \mathrm{wt} \%$ to $70 \mathrm{wt} \%$ nitrate salt, respectively.

- Compared with conventional cement grout waste forms, polyethylene encapsulation of SST nitrate salt wastes can reduce long-term leachability by 25 to 75 times.

- Elevated temperatures appear to have negligible impact on polyethylene waste form mechanical properties and durability. 
- Waste form test specimens stored at temperatures of $70^{\circ} \mathrm{C}$ for up to 3 months showed no significant change in weight or dimensions.

- Compressive yield strength for polyethylene waste forms containing sodium nitrate waste was unaffected by thermal conditioning of $70^{\circ} \mathrm{C}$ for up to 3 months.

Additional testing for Phase I of this effort is scheduled to be completed in FY 1993. This work will focus on examination of the effects of elevated temperature at longer time intervals, potential impacts on waste form properties due to elevated temperature creep, and possible synergistic effects of irradiation at elevated temperatures. Upon successful completion of Phase I, waste form development and testing using SST LLW surrogates will be initiated, leading to scale-up feasibility and full-scale demonstration of the polyethylene encapsulation process for SST LLW surrogates. 


\section{REFERENCES}

1. La Barge, F., et al., "UST-ID Critical Path, Number 1, October 1991 - April 1992," WHCMR-0387-1, Westinghouse Hanford Co., Richland, WA, July 1992.

2. Washington State Dept. of Ecology, U.S. EPA, and U.S. DOE, "Hanford Federal Facility Agreement and Consent Order," EPA Docket Number 1089-03-04-120, May 1989.

3. Kalb, P.D. and P. Colombo, "Polyethylene Solidification of Low-Level Wastes, Topical Report," BNL-51867, Brookhaven National Laboratory, Upton, NY, October 1984.

4. Kalb, P.D., and P. Colombo, "An Economic Analysis of a Volume Reduction /Polyethylene Solidification System for Low-Level Radioactive Wastes," BNL-51866, Brookhaven National Laboratory, Upton, NY, January 1985.

5. Franz, E.M., J.H. Heiser, III, and P. Colombo, "Immobilization of Sodium Nitrate Waste With Polymers, Topical Report," BNL52081, Brookhaven National Laboratory, Upton, NY, April 1987.

6. Kalb, P.D., J.H. Heiser, III, and P. Colombo, "Polyethylene Encapsulation of Nitrate Salt Wastes: Waste Form Stability, Process Scale-up, and Economics," BNL- 52293, Brookhaven National Laboratory, Upton NY, July 1991.

7. Heiser, J.H. IIl, E.M. Franz, and P. Colombo, "A Process for Solidifying Sodium Nitrate Waste in Polyethylene," Environmental Aspects of Stabilization and Solidification of Hazardous and Radioactive Wastes, ASTM STP 1033, P. Cote and M. Gilliam, eds, American Society for Testing and Materials, Philadelphia, 1989.

8. "Technology Program Plan for Closure of the Single-Shell Tank Operable Units," WHC-EP0228, Westinghouse Hanford Co., Richland, WA.

9. McLaughlin, T.J., D.A. Lamar, and S.J. Phillips, "Third Party Technical Workshop on Hanford Single-Shell Tank Waste and Residuals," Bovay Northwest, Inc., Spokane, WA, July 1990.

10. Boomer, K.D., et al., "Systems Engineering Study for the Closure of Single-Shell Tanks" WHC-EP-0405, Westinghouse Hanford Co., Richland, WA, August 1991.

11. Wiemers, K.D., "Preliminary Assessment of Candidate Immobilization Technologies for Retrieved Single-Shell Tank Wastes," PNL-7918, Pacific Northwest Laboratory, Richland, WA, January 1992.

12. Tank Waste Remediation System (TWRS) LLW Disposal Technology Working Group, Proceedings of the TWRS National Technology Workshop, Richland, WA, June 29 - July $1,1992$. 
Polyethylene Encapsulation of SST LLW Annual Report

13. Rouse, J.K., et al., "Underground Storage Tank Integrated Demonstration Functional Requirements," WHC-EP-0566 (Draft), Westinghouse Hanford Co., Richland, WA, April 1992.

14. Boomer, K.D., et al, "Functional Requirements Baseline for the Closure of Single-Shell Tanks," WHC-EP0338, Westinghouse Hanford Co., Richland, WA, June 1990.

15. Hanlon, B.M., "Tank Farm Surveillance and Waste Status Summary Report for March 1992," WHC-EP-0182-48, Westinghouse Hanford Co., Richland, WA, June 1992.

16. Fuhrmann, M., et al., "Method for Accelerated Leaching of Solidified Waste," BNL-52268, Brookhaven National Laboratory, Upton, NY, November 1990.

17. Fuhrmann, M., et al., "Users' Guide for the Accelerated Leach Test Computer Program," BNL-52267, Brookhaven National Laboratory, Upton, NY, November 1990.

18. Fuhrmann, M., et al, "Optimization of the Factors That Accelerate Leaching," BNL-52204, Brookhaven National Laboratory, Upton, NY, March 1989. 
APPENDIX 
Feeder Calibration Data:

$\begin{array}{lllr}\text { Date: } & \text { 10/28/91 } & \text { Material: } & \text { LDPE } \\ \text { Feeder: } & \text { Helix: } & 0.5^{\prime \prime} \\ & & \text { Tube: } & 0.75^{n}\end{array}$

\begin{tabular}{|c|c|c|c|c|c|}
\hline \multirow[b]{2}{*}{ Trial No. } & \multicolumn{5}{|c|}{ Feed Rate, g/min } \\
\hline & 100 & 250 & 500 & 750 & 900 \\
\hline 1 & 14.99 & 36.6 & 101 & 154.7 & 187.91 \\
\hline 2 & 15.51 & 37.74 & 100.5 & 155.33 & 188.86 \\
\hline 3 & 14.85 & 37.74 & 99.7 & 153.97 & 187.69 \\
\hline 4 & 14.88 & 38.32 & 102.1 & 154.1 & 189.62 \\
\hline 5 & 15.89 & 37.82 & 100.8 & 154.02 & 189.29 \\
\hline 6 & 15.61 & 37.82 & 100.5 & 156.46 & 189.91 \\
\hline 7 & 14.81 & 38.58 & 99.85 & 155.6 & 191 \\
\hline 8 & 15.34 & 38.16 & 100.41 & 154.47 & 190.92 \\
\hline 9 & 14.86 & 37.8 & 101.72 & 156.91 & 190.95 \\
\hline 10 & 15.28 & 38.44 & 100.31 & 154.98 & 191.36 \\
\hline Total & 152.02 & 379.02 & 1006.89 & 1550.54 & 1897.51 \\
\hline Mean & 15.20 & 37.90 & 100.69 & 155.05 & 189.75 \\
\hline Std. Dev. & 0.361 & 0.526 & 0.717 & 0.971 & 1.251 \\
\hline Absolute Error & 0.258 & 0.376 & 0.513 & 0.694 & 0.895 \\
\hline Relative Error, \% & 1.70 & 0.99 & 0.51 & 0.45 & 0.47 \\
\hline
\end{tabular}

\begin{tabular}{|cclr|}
\hline \multicolumn{2}{|l}{ Feeder B, Linear Regression Analysis: } & \multicolumn{2}{c|}{ Regression Output: } \\
Speed & Constant & $\mathbf{- 1 1 . 7 1 1 4}$ \\
100 & Output, g/min & Std Err of Y Est & $\mathbf{4 . 4 8 8 1 6 9}$ \\
250 & 15.20 & R Squared & 0.997282 \\
500 & 37.90 & & \\
750 & 100.69 & & \\
900 & 155.97 & & \\
& 189.75 & No. of Observations & \\
& & Degrees of Freedom & \\
& & X Coefficient(s) & 0.223228 \\
& & Std Err of Coef. & 0.006728 \\
\hline
\end{tabular}


flie dpe50ust

Density of Polyethylene/ 50 wt\% NaNO3

UST-ID TTP\# CH321201

Thermal Conditioning Specimens

\begin{tabular}{|c|c|c|c|c|c|c|c|c|}
\hline Sample No & $\begin{array}{c}\text { Welght } \\
\text { (gm) }\end{array}$ & $\begin{array}{l}\text { Height } \\
\text { (mm) }\end{array}$ & $\begin{array}{c}\text { Top Dia. } \\
\text { (mm) }\end{array}$ & $\begin{array}{l}\text { Mid Dia. } \\
\text { (mm) }\end{array}$ & $\begin{array}{r}\text { Bot Dia. } \\
\text { (mm) }\end{array}$ & $\begin{array}{c}\text { Radius } \\
\text { (mm) }\end{array}$ & $\begin{array}{c}\text { Volume } \\
\text { (mL) }\end{array}$ & $\begin{array}{c}\text { Density } \\
(\mathrm{gm} / \mathrm{cm} 3)\end{array}$ \\
\hline 1 & 195.03 & 90.79 & 45.80 & 45.97 & 45.60 & 22.99 & 150.69 & 1.294 \\
\hline 2 & 186.78 & 88.39 & 46.06 & 45.83 & 45.69 & 22.92 & 145.81 & 1.281 \\
\hline 3 & 192.81 & 90.20 & 46.25 & 46.05 & 45.87 & 23.03 & 150.23 & 1.283 \\
\hline 4 & 194.16 & 90.27 & 46.07 & 45.99 & 46.26 & 23.00 & 149.95 & 1.295 \\
\hline 5 & 196.77 & 91.27 & 46.81 & 46.32 & 46.04 & 23.16 & 153.80 & 1.279 \\
\hline 6 & 195.28 & 89.97 & 46.25 & 46.42 & 46.55 & 23.21 & 152.26 & 1.283 \\
\hline 7 & 196.35 & 90.99 & 46.15 & 46.06 & 46.37 & 23.03 & 151.61 & 1.295 \\
\hline 8 & 198.78 & 92.16 & 46.62 & 46.46 & 46.12 & 23.23 & 156.24 & 1.272 \\
\hline 9 & 199.96 & 92.06 & 46.61 & 46.52 & 46.36 & 23.26 & 156.47 & 1.278 \\
\hline 10 & 195.90 & 90.52 & 46.60 & 46.46 & 46.37 & 23.23 & 153.46 & 1.277 \\
\hline 11 & 195.07 & 91.78 & 46.45 & 46.24 & 46.02 & 23.12 & 154.13 & 1.266 \\
\hline 12 & 196.48 & 90.67 & 46.44 & 46.45 & 46.21 & 23.23 & 153.65 & 1.279 \\
\hline 13 & 196.58 & 92.22 & 46.19 & 46.17 & 46.54 & 23.09 & 154.40 & 1.273 \\
\hline 14 & 197.94 & 91.44 & 46.61 & 46.51 & 46.10 & 23.26 & 155.35 & 1.274 \\
\hline 15 & 198.35 & 91.50 & 46.01 & 46.01 & 46.68 & 23.01 & 152.13 & 1.304 \\
\hline 16 & 198.78 & 92.21 & 46.49 & 46.30 & 46.22 & 23.15 & 155.25 & 1.280 \\
\hline 17 & 198.35 & 91.92 & 46.46 & 46.35 & 46.40 & 23.18 & 155.10 & 1.279 \\
\hline 18 & 197.52 & 91.02 & 46.56 & 46.23 & 46.00 & 23.12 & 152.78 & 1.293 \\
\hline 19 & 198.03 & 91.51 & 46.55 & 46.67 & 46.09 & 23.34 & 156.54 & 1.265 \\
\hline 20 & 192.78 & 91.17 & 45.70 & 46.27 & 46.2 .2 & 23.14 & 153.30 & 1.258 \\
\hline 21 & 195.37 & 91.04 & 46.23 & 46.27 & 46.45 & 23.14 & 153.08 & 1.276 \\
\hline 22 & 193.73 & 89.38 & 46.46 & 46.60 & 46.02 & 23.30 & 152.44 & 1.271 \\
\hline 23 & 195.84 & 90.22 & 46.72 & 46.55 & 46.23 & 23.28 & 153.54 & 1.275 \\
\hline 24 & 198.25 & 91.69 & 46.78 & 46.52 & 46.15 & 23.26 & 155.84 & 1.272 \\
\hline 25 & 193.46 & 90.91 & 46.11 & 45.95 & 45.97 & 22.98 & 150.76 & 1.283 \\
\hline 26 & 197.10 & 90.90 & 46.72 & 46.51 & 46.18 & 23.26 & 154.44 & 1.276 \\
\hline 27 & 196.68 & 90.84 & 46.68 & 46.53 & 46.33 & 23.27 & 154.47 & 1.273 \\
\hline 28 & 193.41 & 89.33 & 46.46 & 45.69 & 46.35 & 22.85 & 146.46 & 1.321 \\
\hline 29 & 193.56 & 91.21 & 46.61 & 46.45 & 46.22 & 23.23 & 154.56 & 1.252 \\
\hline 30 & 194.48 & 88.83 & 46.42 & 46.36 & 46.40 & 23.18 & 149.95 & 1.297 \\
\hline 31 & 187.20 & 87.18 & 46.17 & 46.15 & 45.98 & 23.08 & 145.83 & 1.284 \\
\hline 32 & 189.65 & 87.93 & 46.20 & 46.02 & 45.92 & 23.01 & 146.26 & 1.297 \\
\hline 33 & 200.69 & 92.10 & 46.23 & 46.12 & 46.32 & 23.06 & 153.86 & 1.304 \\
\hline 34 & 196.88 & 89.92 & 46.24 & 46.16 & 45.97 & 23.08 & 150.48 & 1.308 \\
\hline 35 & 184.42 & 88.92 & 46.23 & 46.14 & 46.14 & 23.07 & 148.68 & 1.240 \\
\hline 36 & 185.82 & 87.41 & 45.90 & 46.07 & 46.31 & 23.0 & 145.71 & 1.275 \\
\hline 37 & 192.15 & 89.57 & 46.21 & 46.01 & 46.21 & 23.01 & 148.92 & 1.290 \\
\hline 38 & 189.62 & 89.02 & 46.35 & 46.02 & 45.98 & $23 . C^{\prime}$ & 148.07 & 1.281 \\
\hline 39 & 189.55 & 88.46 & 46.04 & 45.97 & 45.86 & 22.9 & 146.82 & 1.291 \\
\hline 40 & 167.07 & 81.28 & 46.22 & 46.00 & 45.88 & $23.0 v$ & 135.08 & 1.237 \\
\hline & & & & & $\begin{array}{l}\text { avo radius } \\
\text { avg area, in }\end{array}$ & $\begin{array}{l}23.11713 \\
2.602256\end{array}$ & & \\
\hline & & & & & & \multirow{4}{*}{\multicolumn{2}{|c|}{$\begin{array}{l}\text { Sum } \\
\text { Average } \\
\text { Standard Deviation } \\
\text { Error } \\
\text { \% Error }\end{array}$}} & 51.212 \\
\hline & & & & & & & & 1.280 \\
\hline & & & & & & & & 0.0164 \\
\hline & & & & & & & & $\begin{array}{l}0.0053 \\
0.0041\end{array}$ \\
\hline
\end{tabular}




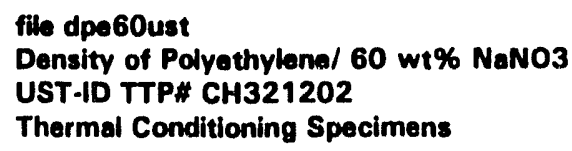

\begin{tabular}{|c|c|c|c|c|c|c|c|c|}
\hline ample No & $\begin{array}{c}\text { Weight } \\
\text { (gm) }\end{array}$ & $\begin{array}{c}\text { Height } \\
\text { (mm) }\end{array}$ & $\begin{array}{c}\text { Top Dia. } \\
\text { (mm) }\end{array}$ & $\begin{array}{l}\text { Mid Dia. } \\
(\mathbf{m m})\end{array}$ & $\begin{array}{l}\text { Bot Dia. } \\
\text { (mm) }\end{array}$ & $\begin{array}{l}\text { Radius } \\
\text { (mm) }\end{array}$ & $\begin{array}{l}\text { Volume } \\
(\mathrm{mL})\end{array}$ & $\begin{array}{c}\text { Density } \\
(\mathrm{gm} / \mathrm{cm} 3)\end{array}$ \\
\hline $\begin{array}{r}1 \\
2 \\
3 \\
4 \\
5 \\
6 \\
7 \\
8 \\
9 \\
10 \\
11 \\
12 \\
13 \\
14 \\
15 \\
16 \\
17 \\
18 \\
19 \\
20 \\
21 \\
22 \\
23 \\
24 \\
25 \\
26 \\
27 \\
28 \\
29 \\
30 \\
31 \\
32 \\
33 \\
34 \\
35 \\
36 \\
37 \\
38 \\
39 \\
40\end{array}$ & $\begin{array}{l}222.00 \\
211.50 \\
218.42 \\
225.18 \\
211.91 \\
209.89 \\
215.65 \\
213.31 \\
212.37 \\
213.18 \\
215.15 \\
216.68 \\
211.63 \\
214.62 \\
212.37 \\
212.45 \\
213.61 \\
214.92 \\
214.89 \\
212.00 \\
210.67 \\
214.76 \\
216.59 \\
212.38 \\
217.61 \\
211.74 \\
214.89 \\
214.05 \\
216.09 \\
213.26 \\
212.63 \\
212.20 \\
217.13 \\
213.57 \\
206.18 \\
212.45 \\
214.10 \\
204.26 \\
214.84 \\
218.89\end{array}$ & $\begin{array}{l}93.68 \\
91.40 \\
91.25 \\
93.60 \\
91.69 \\
89.97 \\
91.64 \\
91.60 \\
91.00 \\
92.20 \\
92.02 \\
92.95 \\
91.42 \\
92.05 \\
91.12 \\
91.54 \\
90.99 \\
91.87 \\
91.78 \\
90.86 \\
90.77 \\
91.60 \\
92.32 \\
90.30 \\
91.99 \\
90.69 \\
91.23 \\
91.77 \\
92.34 \\
92.18 \\
91.74 \\
90.85 \\
93.07 \\
91.88 \\
90.30 \\
90.90 \\
91.89 \\
90.72 \\
91.35 \\
93.15\end{array}$ & $\begin{array}{l}46.40 \\
46.85 \\
46.45 \\
46.75 \\
46.70 \\
46.60 \\
46.35 \\
46.75 \\
46.55 \\
46.35 \\
46.65 \\
46.76 \\
46.40 \\
46.80 \\
46.40 \\
46.52 \\
46.53 \\
46.43 \\
46.80 \\
46.56 \\
46.57 \\
46.67 \\
46.55 \\
46.46 \\
46.52 \\
46.51 \\
46.67 \\
46.28 \\
46.45 \\
46.84 \\
46.36 \\
46.63 \\
46.68 \\
46.68 \\
46.56 \\
46.65 \\
46.40 \\
46.20 \\
46.52 \\
46.58\end{array}$ & $\begin{array}{l}46.60 \\
46.75 \\
46.60 \\
46.50 \\
46.55 \\
46.65 \\
46.47 \\
46.80 \\
46.55 \\
46.40 \\
46.55 \\
46.67 \\
46.45 \\
46.66 \\
46.62 \\
46.76 \\
46.51 \\
46.70 \\
46.69 \\
46.70 \\
46.36 \\
46.63 \\
46.60 \\
46.40 \\
46.60 \\
46.58 \\
46.71 \\
46.33 \\
46.30 \\
46.63 \\
46.40 \\
46.52 \\
46.51 \\
46.52 \\
46.55 \\
46.77 \\
46.58 \\
46.33 \\
46.59 \\
46.63\end{array}$ & $\begin{array}{r}46.50 \\
46.70 \\
46.80 \\
45.90 \\
46.35 \\
46.65 \\
46.60 \\
46.50 \\
46.75 \\
46.80 \\
46.40 \\
46.30 \\
46.47 \\
46.45 \\
46.86 \\
46.71 \\
46.40 \\
46.82 \\
46.67 \\
46.50 \\
46.59 \\
46.60 \\
46.57 \\
\text { avg radius } \\
\text { avg area,in }\end{array}$ & $\begin{array}{r}23.30 \\
23.38 \\
23.30 \\
23.25 \\
23.28 \\
23.33 \\
23.24 \\
23.40 \\
23.28 \\
23.20 \\
23.28 \\
23.34 \\
23.23 \\
23.33 \\
23.31 \\
23.38 \\
23.26 \\
23.35 \\
23.35 \\
23.35 \\
23.18 \\
23.32 \\
23.30 \\
23.20 \\
23.30 \\
23.29 \\
23.36 \\
23.17 \\
23.15 \\
23.32 \\
23.20 \\
23.26 \\
23.26 \\
23.26 \\
23.28 \\
23.39 \\
23.29 \\
23.17 \\
23.30 \\
23.32 \\
23.284 \\
2.639962\end{array}$ & $\begin{array}{l}159.77 \\
156.89 \\
155.63 \\
158.95 \\
156.05 \\
153.78 \\
155.42 \\
157.57 \\
154.87 \\
155.90 \\
156.61 \\
159.01 \\
154.92 \\
157.40 \\
155.54 \\
157.20 \\
154.59 \\
157.36 \\
157.14 \\
155.63 \\
153.22 \\
156.43 \\
157.46 \\
152.69 \\
156.89 \\
154.54 \\
156.33 \\
154.71 \\
155.47 \\
157.42 \\
155.13 \\
154.42 \\
158.12 \\
156.17 \\
153.68 \\
156.17 \\
156.59 \\
152.94 \\
155.73 \\
159.08\end{array}$ & $\begin{array}{l}1.389 \\
1.348 \\
1.403 \\
1.417 \\
1.358 \\
1.365 \\
1.387 \\
1.354 \\
1.371 \\
1.367 \\
1.374 \\
1.363 \\
1.366 \\
1.364 \\
1.365 \\
1.351 \\
1.382 \\
1.366 \\
1.368 \\
1.362 \\
1.375 \\
1.373 \\
1.376 \\
1.391 \\
1.387 \\
1.370 \\
1.375 \\
1.384 \\
1.390 \\
1.355 \\
1.371 \\
1.374 \\
1.373 \\
1.368 \\
1.342 \\
1.360 \\
1.367 \\
1.336 \\
1.380 \\
1.376\end{array}$ \\
\hline & & & & & & \multicolumn{2}{|c|}{$\begin{array}{l}\text { Surm } \\
\text { Average } \\
\text { Standard Doviation } \\
\text { Error } \\
\text { \% Error }\end{array}$} & $\begin{array}{r}54.841 \\
1.371 \\
0.0154 \\
0.0049 \\
0.0036\end{array}$ \\
\hline
\end{tabular}


Density Data for UST-ID Thermal Test Specimens

file dpe70ust

Density of Polyethylene/ 70 wt\% NaNO3

UST-ID TTP" CH321202

Thermal Conditioning Specimens

\begin{tabular}{|c|c|c|c|c|c|c|c|c|}
\hline Sample No & $\begin{array}{l}\text { Woight } \\
\text { (am) }\end{array}$ & $\begin{array}{l}\text { Height } \\
\text { (mm) }\end{array}$ & $\begin{array}{l}\text { Top Dia. } \\
\text { (mm) }\end{array}$ & $\begin{array}{l}\text { Mid Dia. } \\
(\mathbf{m m})\end{array}$ & $\begin{array}{l}\text { Bot Dia. } \\
\text { (mm) }\end{array}$ & $\begin{array}{l}\text { Radius } \\
\text { (mm) }\end{array}$ & $\begin{array}{c}\text { Volume } \\
\text { (mL) }\end{array}$ & $\begin{array}{c}\text { Donsity } \\
\text { (gm/cm3) }\end{array}$ \\
\hline $\begin{array}{r}1 \\
2 \\
3 \\
4 \\
5 \\
6 \\
7 \\
8 \\
9 \\
10 \\
11 \\
12 \\
13 \\
14 \\
15 \\
16 \\
17 \\
18 \\
19 \\
20 \\
21 \\
22 \\
23 \\
24 \\
25 \\
26 \\
27 \\
28 \\
29 \\
30 \\
31 \\
32 \\
33 \\
34 \\
35 \\
36 \\
37 \\
38 \\
39\end{array}$ & $\begin{array}{l}248.60 \\
235.75 \\
248.12 \\
235.73 \\
252.30 \\
250.33 \\
245.30 \\
241.10 \\
250.43 \\
251.04 \\
247.12 \\
246.57 \\
250.32 \\
248.25 \\
239.69 \\
247.41 \\
248.29 \\
246.56 \\
241.92 \\
247.80 \\
247.46 \\
250.93 \\
249.49 \\
239.84 \\
245.46 \\
237.52 \\
248.70 \\
238.74 \\
235.76 \\
235.06 \\
235.89 \\
248.85 \\
236.49 \\
239.35 \\
248.32 \\
241.76 \\
238.15 \\
246.42 \\
237.73\end{array}$ & $\begin{array}{l}91.99 \\
92.57 \\
92.25 \\
91.92 \\
93.04 \\
91.88 \\
90.47 \\
92.03 \\
92.50 \\
92.25 \\
91.33 \\
90.97 \\
92.06 \\
91.59 \\
92.37 \\
90.98 \\
91.35 \\
91.26 \\
92.30 \\
90.62 \\
92.31 \\
92.68 \\
92.07 \\
92.62 \\
91.02 \\
92.11 \\
91.92 \\
92.27 \\
92.91 \\
92.20 \\
91.97 \\
92.06 \\
92.30 \\
93.01 \\
91.49 \\
93.95 \\
91.42 \\
91.87 \\
92.82\end{array}$ & $\begin{array}{l}46.85 \\
46.70 \\
47.10 \\
46.60 \\
46.85 \\
46.80 \\
47.15 \\
46.55 \\
46.15 \\
47.15 \\
47.00 \\
46.95 \\
46.90 \\
46.75 \\
46.88 \\
47.15 \\
46.90 \\
46.80 \\
46.86 \\
47.00 \\
46.99 \\
47.05 \\
47.00 \\
46.95 \\
47.02 \\
46.75 \\
47.10 \\
46.50 \\
46.75 \\
46.65 \\
46.70 \\
46.90 \\
46.70 \\
46.40 \\
46.95 \\
46.77 \\
46.85 \\
46.88 \\
46.70\end{array}$ & $\begin{array}{l}46.75 \\
46.65 \\
46.73 \\
46.70 \\
46.90 \\
46.85 \\
47.05 \\
46.50 \\
46.50 \\
47.00 \\
46.90 \\
47.00 \\
46.55 \\
46.80 \\
46.85 \\
46.78 \\
46.96 \\
46.70 \\
46.68 \\
47.11 \\
46.85 \\
46.90 \\
46.87 \\
47.00 \\
46.91 \\
46.65 \\
46.80 \\
46.85 \\
46.60 \\
46.58 \\
46.75 \\
46.80 \\
46.72 \\
46.52 \\
46.80 \\
46.70 \\
46.80 \\
46.75 \\
46.70\end{array}$ & 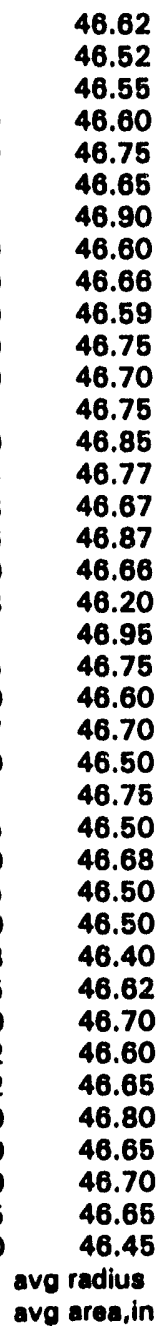 & $\begin{array}{r}23.38 \\
23.33 \\
23.37 \\
23.35 \\
23.45 \\
23.43 \\
23.53 \\
23.25 \\
23.25 \\
23.50 \\
23.45 \\
23.50 \\
23.28 \\
23.40 \\
23.43 \\
23.39 \\
23.48 \\
23.35 \\
23.34 \\
23.56 \\
23.43 \\
23.45 \\
23.44 \\
23.50 \\
23.46 \\
23.33 \\
23.40 \\
23.43 \\
23.30 \\
23.29 \\
23.38 \\
23.40 \\
23.36 \\
23.26 \\
23.40 \\
23.35 \\
23.40 \\
23.38 \\
23.35 \\
23.39115 \\
2.684316\end{array}$ & $\begin{array}{l}157.90 \\
158.22 \\
158.22 \\
157.45 \\
160.73 \\
158.39 \\
157.29 \\
156.29 \\
157.09 \\
160.05 \\
157.78 \\
157.83 \\
156.68 \\
157.55 \\
159.24 \\
156.37 \\
158.22 \\
156.32 \\
157.96 \\
157.96 \\
159.13 \\
160.11 \\
158.85 \\
160.69 \\
157.31 \\
157.43 \\
158.12 \\
159.06 \\
158.46 \\
157.12 \\
157.87 \\
158.36 \\
158.23 \\
158.09 \\
157.38 \\
160.92 \\
157.26 \\
157.70 \\
158.99\end{array}$ & $\begin{array}{l}1.574 \\
1.490 \\
1.568 \\
1.497 \\
1.570 \\
1.580 \\
1.559 \\
1.543 \\
1.594 \\
1.569 \\
1.566 \\
1.562 \\
1.598 \\
1.576 \\
1.505 \\
1.582 \\
1.569 \\
1.577 \\
1.532 \\
1.569 \\
1.555 \\
1.567 \\
1.571 \\
1.493 \\
1.560 \\
1.509 \\
1.573 \\
1.501 \\
1.488 \\
1.496 \\
1.494 \\
1.571 \\
1.495 \\
1.514 \\
1.578 \\
1.502 \\
1.514 \\
1.563 \\
1.495\end{array}$ \\
\hline & & & & & & \multicolumn{2}{|c|}{$\begin{array}{l}\text { Sum } \\
\text { Average } \\
\text { Standard Doviation } \\
\text { Error } \\
\text { \% Error }\end{array}$} & $\begin{array}{r}60.220 \\
1.544 \\
0.0354 \\
0.0113 \\
0.0073\end{array}$ \\
\hline
\end{tabular}

$$
\text { A }-4
$$


file: uat50\%50.wk3

Density of Polyethylene/ 70 wt\% NaNO3

UST-ID TTP* CH321201

Thermal Conditioning Specimens

Weights and Dimensions following 3 month thermal conditioning at 50 degrees $C$

\begin{tabular}{|c|c|c|c|c|c|c|c|c|c|}
\hline & Sample No & $\begin{array}{c}\text { Woight } \\
\text { (gm) }\end{array}$ & $\begin{array}{l}\text { Height } \\
\text { (mm) }\end{array}$ & $\begin{array}{c}\text { Top Dia. } \\
(\mathrm{mm})\end{array}$ & $\begin{array}{l}\text { Mid Dia. } \\
\qquad(\mathrm{mm})\end{array}$ & $\begin{array}{l}\text { Bot Dia. } \\
\text { (mm) }\end{array}$ & $\begin{array}{l}\text { Radius } \\
(\mathbf{m m})\end{array}$ & $\begin{array}{c}\text { Volume } \\
(\mathrm{mL})\end{array}$ & $\begin{array}{c}\text { Density } \\
\text { (gm/cm3) }\end{array}$ \\
\hline $\begin{array}{l}\text { Before } \\
\text { After } \\
\text { Change } \\
\% \text { Change }\end{array}$ & 2 & $\begin{array}{r}186.78 \\
186.68 \\
-0.1 \\
-0.05354\end{array}$ & $\begin{array}{r}88.39 \\
88.4936 \\
0.1036 \\
0.117208\end{array}$ & 46.06 & $\begin{array}{r}45.83 \\
46.3804 \\
0.5504 \\
1.20096\end{array}$ & 45.69 & $\begin{array}{r}22.92 \\
23.19 \\
0.2752 \\
1.20096\end{array}$ & $\begin{array}{r}145.81 \\
149.51 \\
3.698346 \\
2.536383\end{array}$ & $\begin{array}{r}1.281 \\
1.249 \\
-0.03236 \\
-2.52586\end{array}$ \\
\hline $\begin{array}{l}\text { Before } \\
\text { After } \\
\text { Change } \\
\% \text { Change }\end{array}$ & 24 & $\begin{array}{r}198.25 \\
198.24 \\
-0.01 \\
-0.00504\end{array}$ & $\begin{array}{r}91.69 \\
91.694 \\
0.004 \\
0.004363\end{array}$ & 46.78 & $\begin{array}{r}46.52 \\
46.4312 \\
-0.0888 \\
-0.19089\end{array}$ & 46.15 & $\begin{array}{r}23.26 \\
23.22 \\
.0 .0444 \\
-0.19089\end{array}$ & $\begin{array}{r}155.84 \\
155.26 \\
-0.58763 \\
-0.37706\end{array}$ & $\begin{array}{r}1.272 \\
1.277 \\
0.00475 \\
0.373425\end{array}$ \\
\hline $\begin{array}{l}\text { Before } \\
\text { After } \\
\text { Change } \\
\% \text { Change }\end{array}$ & 29 & $\begin{array}{r}193.56 \\
193.51 \\
-0.05 \\
-0.02583\end{array}$ & $\begin{array}{r}91.21 \\
91.1606 \\
-0.0494 \\
-0.05416\end{array}$ & 46.61 & $\begin{array}{r}46.45 \\
46.1264 \\
-0.3236 \\
-0.69666\end{array}$ & 46.22 & $\begin{array}{r}23.23 \\
23.06 \\
-0.1618 \\
-0.69666\end{array}$ & $\begin{array}{r}154.56 \\
152.33 \\
-2.22861 \\
-1.44188\end{array}$ & $\begin{array}{r}1.252 \\
1.270 \\
0.017993 \\
1.436766\end{array}$ \\
\hline $\begin{array}{l}\text { Before } \\
\text { After } \\
\text { Change } \\
\% \text { Change }\end{array}$ & 34 & $\begin{array}{r}196.88 \\
196.88 \\
0 \\
0\end{array}$ & $\begin{array}{r}89.92 \\
89.8144 \\
-0.1056 \\
-0.11744\end{array}$ & 46.24 & $\begin{array}{r}46.16 \\
46.5836 \\
0.4236 \\
0.917678\end{array}$ & 45.97 & $\begin{array}{r}23.08 \\
23.29 \\
0.2118 \\
0.917678\end{array}$ & $\begin{array}{r}150.48 \\
153.07 \\
2.59453 \\
1.724174\end{array}$ & $\begin{array}{r}1.308 \\
1.286 \\
-0.02218 \\
-1.69495\end{array}$ \\
\hline $\begin{array}{l}\text { Before } \\
\text { After } \\
\text { Change } \\
\% \text { Change }\end{array}$ & 39 & $\begin{array}{r}189.55 \\
189.49 \\
-0.06 \\
-0.03165\end{array}$ & $\begin{array}{r}88.46 \\
88.4682 \\
0.0082 \\
0.00927\end{array}$ & 46.04 & $\begin{array}{r}45.97 \\
46.228 \\
0.258 \\
0.561236\end{array}$ & 45.86 & $\begin{array}{r}22.99 \\
23.11 \\
0.129 \\
0.561236\end{array}$ & $\begin{array}{r}146.82 \\
148.49 \\
1.666402 \\
1.134995\end{array}$ & $\begin{array}{r}1.291 \\
1.276 \\
-0.01489 \\
-1.15356\end{array}$ \\
\hline
\end{tabular}


file: ust60\%50.wk3

Density of Polyethylene/ 60 wt\% NaNO3

UST-ID TTP* CH321201

Thermal Conditioning Specimens

Weights and Dimensions following 3 month thermal conditioning at 50 degrees $\mathbf{C}$

\begin{tabular}{|c|c|c|c|c|c|c|c|c|c|}
\hline & Sample No & $\begin{array}{l}\text { Weight } \\
\text { (gm) }\end{array}$ & $\begin{array}{l}\text { Height } \\
\text { (mm) }\end{array}$ & $\begin{array}{l}\text { Top Dia. } \\
\text { (mm) }\end{array}$ & $\begin{array}{l}\text { Mid Dia. } \\
\text { (mm) }\end{array}$ & $\begin{array}{l}\text { Bot Dia. } \\
\text { (mm) }\end{array}$ & $\begin{array}{l}\text { Radius } \\
\text { (mm) }\end{array}$ & $\begin{array}{l}\text { Volume } \\
\text { (mL) }\end{array}$ & $\begin{array}{c}\text { Density } \\
(\mathrm{gm} / \mathrm{cm} 3)\end{array}$ \\
\hline $\begin{array}{l}\text { Before } \\
\text { After } \\
\text { Change } \\
\% \text { Change }\end{array}$ & 6 & $\begin{array}{r}209.89 \\
209.87 \\
-0.02 \\
-0.00953\end{array}$ & $\begin{array}{r}89.97 \\
89.8906 \\
-0.0794 \\
-0.08825\end{array}$ & 46.60 & $\begin{array}{r}46.65 \\
46.355 \\
-0.295 \\
-0.63237\end{array}$ & 46.65 & $\begin{array}{r}23.33 \\
23.18 \\
-0.1475 \\
-0.63237\end{array}$ & $\begin{array}{r}153.78 \\
151.70 \\
-2.07272 \\
-1.34788\end{array}$ & $\begin{array}{r}1.365 \\
1.383 \\
0.018517 \\
1.356634\end{array}$ \\
\hline $\begin{array}{l}\text { Before } \\
\text { After } \\
\text { Change } \\
\text { \% Change }\end{array}$ & 23 & $\begin{array}{r}216.59 \\
216.48 \\
-0.11 \\
-0.05079\end{array}$ & $\begin{array}{r}92.32 \\
91.9988 \\
-0.3212 \\
-0.34792\end{array}$ & 46.55 & $\begin{array}{r}46.60 \\
46.5836 \\
-0.0164 \\
-0.03519\end{array}$ & 46.57 & $\begin{array}{r}23.30 \\
23.29 \\
-0.0082 \\
-0.03519\end{array}$ & $\begin{array}{r}157.46 \\
156.80 \\
-0.65824 \\
-0.41805\end{array}$ & $\begin{array}{r}1.376 \\
1.381 \\
0.005073 \\
0.368804\end{array}$ \\
\hline $\begin{array}{l}\text { Before } \\
\text { After } \\
\text { Change } \\
\% \text { Change }\end{array}$ & 32 & $\begin{array}{r}212.20 \\
212.23 \\
0.03 \\
0.014138\end{array}$ & $\begin{array}{r}90.85 \\
90.7288 \\
-0.1212 \\
-0.13341\end{array}$ & 46.63 & $\begin{array}{r}46.52 \\
46.7614 \\
0.2414 \\
0.518917\end{array}$ & 46.75 & $\begin{array}{r}23.26 \\
23.38 \\
0.1207 \\
0.518917\end{array}$ & $\begin{array}{r}154.42 \\
155.82 \\
1.3986 \\
0.905731\end{array}$ & $\begin{array}{r}1.374 \\
1.362 \\
-0.01214 \\
-0.88359\end{array}$ \\
\hline $\begin{array}{l}\text { Before } \\
\text { After } \\
\text { Change } \\
\% \text { Change }\end{array}$ & 39 & $\begin{array}{r}214.84 \\
214.82 \\
-0.02 \\
-0.00931\end{array}$ & $\begin{array}{r}91.35 \\
91.313 \\
-0.037 \\
-0.0405\end{array}$ & 46.52 & $\begin{array}{r}46.59 \\
46.7106 \\
0.1206 \\
0.258854\end{array}$ & 46.66 & $\begin{array}{r}23.30 \\
23.36 \\
0.0603 \\
0.258854\end{array}$ & $\begin{array}{r}155.73 \\
156.48 \\
0.743886 \\
0.477664\end{array}$ & $\begin{array}{r}1.380 \\
1.373 \\
-0.00669 \\
-0.48466\end{array}$ \\
\hline $\begin{array}{l}\text { Before } \\
\text { After } \\
\text { Change } \\
\% \text { Change }\end{array}$ & 40 & $\begin{array}{r}218.89 \\
218.79 \\
-0.1 \\
-0.04569\end{array}$ & $\begin{array}{r}93.15 \\
93.0148 \\
-0.1352 \\
-0.14514\end{array}$ & 46.58 & $\begin{array}{r}46.63 \\
46.5836 \\
-0.0464 \\
-0.09951\end{array}$ & 46.59 & $\begin{array}{r}23.32 \\
23.29 \\
-0.0232 \\
-0.09951\end{array}$ & $\begin{array}{r}159.08 \\
158.53 \\
-0.54685 \\
-0.34377\end{array}$ & $\begin{array}{r}1.376 \\
1.380 \\
0.004116 \\
0.299111\end{array}$ \\
\hline
\end{tabular}


file: ust 70\%50.wk3

Density of Polyethylene/ 70 wt\% NaNO3

UST-ID TTP\# CH321201

Thermal Conditioning Specimens

Weights and Dimensions following 3 month thermal conditioning at 50 degrees $C$

\begin{tabular}{|c|c|c|c|c|c|c|c|c|c|}
\hline & Sample No & $\begin{array}{c}\text { Weight } \\
\text { (gm) }\end{array}$ & $\begin{array}{c}\text { Height } \\
\text { (mm) }\end{array}$ & $\begin{array}{l}\text { Top Dia. } \\
\text { (mm) }\end{array}$ & $\begin{array}{l}\text { Mid Dia. } \\
\text { (mm) }\end{array}$ & $\begin{array}{l}\text { Bot Dia. } \\
\text { (mm) }\end{array}$ & $\begin{array}{l}\text { Radius } \\
(\mathrm{mm})\end{array}$ & $\begin{array}{c}\text { Volume } \\
(\mathrm{mL})\end{array}$ & $\begin{array}{l}\text { Density } \\
\text { (gm/cm3) }\end{array}$ \\
\hline $\begin{array}{l}\text { Before } \\
\text { After } \\
\text { Change } \\
\% \text { Change }\end{array}$ & 3 & $\begin{array}{r}248.12 \\
248.24 \\
0.12 \\
0.048364\end{array}$ & $\begin{array}{r}92.25 \\
92.1766 \\
-0.0734 \\
-0.07957\end{array}$ & 47.10 & $\begin{array}{r}46.73 \\
46.9392 \\
0.2092 \\
0.447678\end{array}$ & 46.55 & $\begin{array}{r}23.37 \\
23.47 \\
0.1046 \\
0.447678\end{array}$ & $\begin{array}{r}158.22 \\
159.51 \\
1.292744 \\
0.81708\end{array}$ & $\begin{array}{r}1.568 \\
1.556 \\
-0.01196 \\
-0.76249\end{array}$ \\
\hline $\begin{array}{l}\text { Before } \\
\text { After } \\
\text { Change } \\
\text { \% Change }\end{array}$ & 15 & $\begin{array}{r}239.69 \\
239.61 \\
-0.08 \\
-0.03338\end{array}$ & $\begin{array}{r}92.37 \\
92.3544 \\
-0.0156 \\
-0.01689\end{array}$ & 46.88 & $\begin{array}{r}46.85 \\
46.9646 \\
0.1146 \\
0.24461\end{array}$ & 46.77 & $\begin{array}{r}23.43 \\
23.48 \\
0.0573 \\
0.24461\end{array}$ & $\begin{array}{r}159.24 \\
159.99 \\
0.752942 \\
0.472848\end{array}$ & $\begin{array}{r}1.505 \\
1.498 \\
-0.00758 \\
-0.50384\end{array}$ \\
\hline $\begin{array}{l}\text { Before } \\
\text { After } \\
\text { Change } \\
\% \text { Change }\end{array}$ & 30 & $\begin{array}{r}235.06 \\
235.03 \\
-0.03 \\
-0.01276\end{array}$ & $\begin{array}{r}92.20 \\
92.1512 \\
-0.0488 \\
-0.05293\end{array}$ & 46.65 & $\begin{array}{r}46.58 \\
46.4312 \\
-0.1488 \\
-0.31945\end{array}$ & 46.40 & $\begin{array}{r}23.29 \\
23.22 \\
-0.0744 \\
-0.31945\end{array}$ & $\begin{array}{r}157.12 \\
156.03 \\
-1.08484 \\
-0.69047\end{array}$ & $\begin{array}{r}1.496 \\
1.506 \\
0.01021 \\
0.68242\end{array}$ \\
\hline $\begin{array}{l}\text { Before } \\
\text { After } \\
\text { Change } \\
\% \text { Change }\end{array}$ & 35 & $\begin{array}{r}248.32 \\
248.38 \\
0.06 \\
0.024162\end{array}$ & $\begin{array}{r}91.49 \\
91.5416 \\
0.0516 \\
0.0564\end{array}$ & 46.95 & $\begin{array}{r}46.80 \\
46.863 \\
0.063 \\
0.134615\end{array}$ & 46.80 & $\begin{array}{r}23.40 \\
23.43 \\
0.0315 \\
0.134615\end{array}$ & $\begin{array}{r}157.38 \\
157.90 \\
0.513008 \\
0.325964\end{array}$ & $\begin{array}{r}1.578 \\
1.573 \\
-0.00475 \\
-0.30082\end{array}$ \\
\hline $\begin{array}{l}\text { Before } \\
\text { After } \\
\text { Change } \\
\% \text { Change }\end{array}$ & 37 & $\begin{array}{r}238.15 \\
7381 \\
-0.05 \\
-0.021\end{array}$ & $\begin{array}{r}91.42 \\
91.4146 \\
-0.0054 \\
-0.00591\end{array}$ & 46.85 & $\begin{array}{r}46.80 \\
46.1772 \\
-0.6228 \\
-1.33077\end{array}$ & 46.70 & $\begin{array}{r}23.40 \\
23.09 \\
-0.3114 \\
-1.33077\end{array}$ & $\begin{array}{r}157.26 \\
153.09 \\
-4.16677 \\
-2.64958\end{array}$ & $\begin{array}{r}1.514 \\
1.555 \\
0.04089 \\
2.700126\end{array}$ \\
\hline
\end{tabular}


file: ust50\%70.wk3

Density of Polyethylene/ 50 wt\% NaNO3

UST-ID TTP柋 CH321201

Thermal Conditioning Specimens

Weights and Dimensions following 3 month thermel conditioning at 70 degrees $C$

\begin{tabular}{|c|c|c|c|c|c|c|c|c|c|}
\hline & Semple No & $\begin{array}{c}\text { Weight } \\
\text { (am) }\end{array}$ & $\begin{array}{l}\text { Height } \\
\text { (mm) }\end{array}$ & $\begin{array}{l}\text { Top Dis. } \\
\text { (mm) }\end{array}$ & $\begin{array}{l}\text { Mid Dia. } \\
\text { (mm) }\end{array}$ & $\begin{array}{l}\text { Bot Dis. } \\
\text { (mm) }\end{array}$ & $\begin{array}{l}\text { Radius } \\
\text { (mm) }\end{array}$ & $\begin{array}{l}\text { Volume } \\
\text { (mL) }\end{array}$ & $\begin{array}{c}\text { Density } \\
(\mathrm{gm} / \mathrm{cm} 3)\end{array}$ \\
\hline $\begin{array}{l}\text { Before } \\
\text { After } \\
\text { Change } \\
\text { \% Change }\end{array}$ & 9 & $\begin{array}{r}199.96 \\
200.06 \\
0.1 \\
0.05001\end{array}$ & $\begin{array}{r}92.06 \\
92.075 \\
0.015 \\
0.016294\end{array}$ & 46.61 & $\begin{array}{r}46.52 \\
46.2534 \\
-0.2666 \\
-0.57309\end{array}$ & 46.36 & $\begin{array}{r}23.26 \\
23.13 \\
-0.1333 \\
-0.57309\end{array}$ & $\begin{array}{r}156.47 \\
154.71 \\
-1.76311 \\
-1.12678\end{array}$ & $\begin{array}{r}1.278 \\
1.293 \\
0.01521 \\
1.190203\end{array}$ \\
\hline $\begin{array}{l}\text { Before } \\
\text { After } \\
\text { Change } \\
\% \text { Change }\end{array}$ & 21 & $\begin{array}{r}195.37 \\
195.47 \\
0.1 \\
0.051185\end{array}$ & $\begin{array}{r}91.04 \\
91.1352 \\
0.0952 \\
0.104569\end{array}$ & 46.23 & $\begin{array}{r}46.27 \\
46.5074 \\
0.2374 \\
0.513075\end{array}$ & 46.45 & $\begin{array}{r}23.14 \\
23.25 \\
0.1187 \\
0.513075\end{array}$ & $\begin{array}{r}153.08 \\
154.82 \\
1.736594 \\
1.134429\end{array}$ & $\begin{array}{r}1.276 \\
1.263 \\
-0.01367 \\
-1.07109\end{array}$ \\
\hline $\begin{array}{l}\text { Before } \\
\text { After } \\
\text { Change } \\
\% \text { Change }\end{array}$ & 27 & $\begin{array}{r}196.68 \\
196.77 \\
0.09 \\
0.04576\end{array}$ & $\begin{array}{r}90.84 \\
90.8812 \\
0.0412 \\
0.045354\end{array}$ & 46.68 & $\begin{array}{r}46.53 \\
46.6598 \\
0.1298 \\
0.27896\end{array}$ & 46.33 & $\begin{array}{r}23.27 \\
23.33 \\
0.0649 \\
0.27896\end{array}$ & $\begin{array}{r}154.47 \\
155.40 \\
0.933447 \\
0.604306\end{array}$ & $\begin{array}{r}1.273 \\
1.266 \\
-0.00707 \\
-0.55519\end{array}$ \\
\hline $\begin{array}{l}\text { Before } \\
\text { After } \\
\text { Change } \\
\text { \% Change }\end{array}$ & 32 & $\begin{array}{r}189.65 \\
189.73 \\
0.08 \\
0.042183\end{array}$ & $\begin{array}{r}87.93 \\
87.8586 \\
-0.0714 \\
-0.0812\end{array}$ & 46.20 & $\begin{array}{r}46.02 \\
45.5168 \\
-0.5032 \\
-1.09344\end{array}$ & 45.92 & $\begin{array}{r}23.01 \\
22.76 \\
-0.2516 \\
-1.09344\end{array}$ & $\begin{array}{r}146.26 \\
142.96 \\
-3.29718 \\
-2.25435\end{array}$ & $\begin{array}{r}1.297 \\
1.327 \\
0.030466 \\
2.349503\end{array}$ \\
\hline $\begin{array}{l}\text { Before } \\
\text { After } \\
\text { Change } \\
\% \text { Change }\end{array}$ & 36 & $\begin{array}{r}185.82 \\
185.89 \\
0.07 \\
0.037671\end{array}$ & $\begin{array}{r}87.41 \\
87.1982 \\
-0.2118 \\
-0.24231\end{array}$ & 45.90 & $\begin{array}{r}46.07 \\
46.5836 \\
0.5136 \\
1.114825\end{array}$ & 46.31 & $\begin{array}{r}23.04 \\
23.29 \\
0.2568 \\
1.114825\end{array}$ & $\begin{array}{r}145.71 \\
148.62 \\
2.90594 \\
1.99434\end{array}$ & $\begin{array}{r}1.275 \\
1.251 \\
-0.02447 \\
-1.91841\end{array}$ \\
\hline
\end{tabular}


file: ust60\%70.wk3

Density of Polyethylene/ 60 wt\% NaNO3

UST-ID TTP\# CH321201

Thermal Conditioning Specimens

Weights and Dimensions following 3 month thermal conditioning at 70 degrees $C$

\begin{tabular}{|c|c|c|c|c|c|c|c|c|c|}
\hline & Sample No & $\begin{array}{c}\text { Weight } \\
\text { (gm) }\end{array}$ & $\begin{array}{c}\text { Height } \\
\text { (mm) }\end{array}$ & $\begin{array}{c}\text { Top Dia. } \\
\text { (mm) }\end{array}$ & $\begin{array}{l}\text { Mid Dia. } \\
\text { (mm) }\end{array}$ & $\begin{array}{l}\text { Bot Dia. } \\
\text { (mm) }\end{array}$ & $\begin{array}{c}\text { Radius } \\
\text { (mm) }\end{array}$ & $\begin{array}{c}\text { Volume } \\
\text { (mL) }\end{array}$ & $\begin{array}{c}\text { Density } \\
\text { (gm/cm3) }\end{array}$ \\
\hline $\begin{array}{l}\text { Before } \\
\text { After } \\
\text { Change } \\
\text { \% Change }\end{array}$ & 7 & $\begin{array}{r}215.65 \\
215.69 \\
0.04 \\
0.018549\end{array}$ & $\begin{array}{r}91.64 \\
91.6432 \\
0.0032 \\
0.003492\end{array}$ & 46.35 & $\begin{array}{r}46.47 \\
46.0502 \\
-0.4198 \\
-0.90338\end{array}$ & 46.60 & $\begin{array}{r}23.24 \\
23.03 \\
-0.2099 \\
-0.90338\end{array}$ & $\begin{array}{r}155.42 \\
152.63 \\
-2.79013 \\
-1.79517\end{array}$ & $\begin{array}{r}1.387 \\
1.413 \\
0.025625 \\
1.84687\end{array}$ \\
\hline $\begin{array}{l}\text { Before } \\
\text { After } \\
\text { Change } \\
\% \text { Change }\end{array}$ & 14 & $\begin{array}{r}214.62 \\
214.64 \\
0.02 \\
0.009319\end{array}$ & $\begin{array}{r}92.05 \\
92.0242 \\
-0.0258 \\
-0.02803\end{array}$ & 46.80 & $\begin{array}{r}46.66 \\
46.7106 \\
0.0506 \\
0.108444\end{array}$ & 46.45 & $\begin{array}{r}23.33 \\
23.36 \\
0.0253 \\
0.108444\end{array}$ & $\begin{array}{r}157.40 \\
157.70 \\
0.297354 \\
0.188917\end{array}$ & $\begin{array}{r}1.364 \\
1.361 \\
-0.00244 \\
-0.17926\end{array}$ \\
\hline $\begin{array}{l}\text { Before } \\
\text { After } \\
\text { Change } \\
\% \text { Change }\end{array}$ & 19 & $\begin{array}{r}214.89 \\
214.95 \\
0.06 \\
0.027921\end{array}$ & $\begin{array}{r}91.78 \\
91.8464 \\
0.0664 \\
0.072347\end{array}$ & 46.80 & $\begin{array}{r}46.69 \\
46.8122 \\
0.1222 \\
0.261726\end{array}$ & 46.67 & $\begin{array}{r}23.55 \\
23.41 \\
0.0611 \\
0.261726\end{array}$ & $\begin{array}{r}157.14 \\
158.08 \\
0.937909 \\
0.596864\end{array}$ & $\begin{array}{r}1.368 \\
1.360 \\
-0.00773 \\
-0.56557\end{array}$ \\
\hline $\begin{array}{l}\text { Before } \\
\text { After } \\
\text { Change } \\
\% \text { Change }\end{array}$ & 22 & $\begin{array}{r}214.76 \\
214.78 \\
0.02 \\
0.009313\end{array}$ & $\begin{array}{r}91.60 \\
91.7448 \\
0.1448 \\
0.158079\end{array}$ & 46.67 & $\begin{array}{r}46.63 \\
46.6344 \\
0.0044 \\
0.009436\end{array}$ & 46.60 & $\begin{array}{r}23.32 \\
23.32 \\
0.0022 \\
0.009436\end{array}$ & $\begin{array}{r}156.43 \\
156.71 \\
0.276849 \\
0.176981\end{array}$ & $\begin{array}{r}1.373 \\
1.371 \\
-0.0023 \\
-0.16737\end{array}$ \\
\hline $\begin{array}{l}\text { Before } \\
\text { After } \\
\text { Change } \\
\% \text { Change }\end{array}$ & 31 & $\begin{array}{r}212.63 \\
212.67 \\
0.04 \\
0.018812\end{array}$ & $\begin{array}{r}91.74 \\
91.5924 \\
-0.1476 \\
-0.16089\end{array}$ & 46.36 & $\begin{array}{r}46.40 \\
46.6852 \\
0.2852 \\
0.614655\end{array}$ & 46.43 & $\begin{array}{r}23.20 \\
23.34 \\
0.142 .6 \\
0.614655\end{array}$ & $\begin{array}{r}155.13 \\
156.79 \\
1.660182 \\
1.070215\end{array}$ & $\begin{array}{r}1.371 \\
1.356 \\
-0.01426 \\
-1.04027\end{array}$ \\
\hline
\end{tabular}


file: ust $70 \% 70 . w k 3$

Density of Polyethylene/ 70 wt\% NaNO3

UST-ID TTP\# CH321201

Thermal Conditioning Specimens

Weights and Dimensions following 3 month thermal conditioning at 70 degrees C

Sample No Weight Height Top Dia. Mid Dis. Bot Dia. Radius Volume Density

$(\mathrm{gm}) \quad(\mathrm{mm}) \quad(\mathrm{mm}) \quad(\mathrm{mm}) \quad(\mathrm{mm}) \quad(\mathrm{mm}) \quad(\mathrm{mL}) \quad(\mathrm{gm} / \mathrm{cm} 3)$

After

Change

\% Change

Igm!

-1..

$\begin{array}{lll}19 & 241.92 & 92.30\end{array}$

46.86

46.68

46.20

23.34

23.14

$157.96 \quad 1.532$

$242.02 \quad 92.202$

46.2788

$-0.4012$

$0.041336 \quad-0.10618$

$-0.85947$

$-0.2006$

$-0.85947$

$155.09 \quad 1.560$

$\begin{array}{ll}-2.86845 & 0.02897\end{array}$

$20 \quad 247.80 \quad 90.62$

$47.00 \quad 47.11$

47.2948

0.1848

After

$247.91 \quad 90.6272$

0.110 .0072

0.392273

46.95

$23.56 \quad 157.96 \quad 1.569$

$\begin{array}{lll}23.65 & 159.21 & 1.557\end{array}$

$\begin{array}{lll}0.0924 & 1.25433 & -0.01167\end{array}$

$\%$ Change

0.0443910 .007945

Before

After

Change

$\%$ Change

$\begin{array}{lll}28 & 238.74 & 92.27\end{array}$

$238.76 \quad 92.2528$

$0.02-0.0172$

$0.008377-0.01864$

$46.50 \quad 46.85$

46.7868

$-0.0632$

$-0.1349$

Before

After

Change

$\%$ Change

29

$$
\begin{array}{rr}
235.76 & 92.91 \\
235.79 & 92.9132 \\
0.03 & 0.0032
\end{array}
$$

0.0127250 .003444

Before

After

Change

$\%$ Change

$\begin{array}{rrr}36 & 241.76 & 93.95 \\ 241.74 & 93.9038 \\ -0.02 & -0.0462 \\ -0.00827 & -0.04918\end{array}$

$\begin{array}{rr}46.75 & 46.60 \\ & 46.5328\end{array}$

$-0.0672$

$-0.14421$

46.50

392273

$0.794093-0.7438$

$46.77 \quad 46.70$

46.9646

0.2646

0.566595

$\begin{array}{rrrrr}46.65 & 23.35 & 160.92 & 1.502 \\ 23.48 & 162.67 & 1.486 \\ 0.1323 & 1.748706 & -0.01627 \\ 0.566595 & 1.086667 & -1.08317\end{array}$

A - 10 


\section{Polyethylene Waste Form Compressive Strength \\ $50 w t \%$ Sodium Nitrate}

Control Specimens (Stored at Ambient Temp)

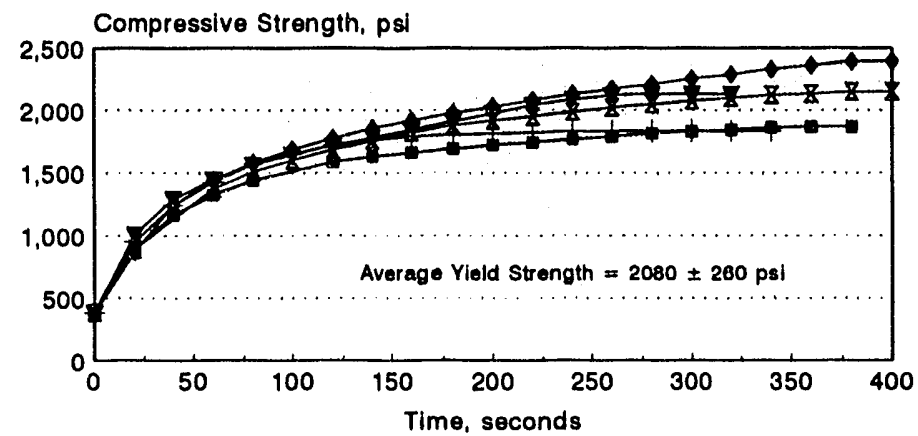

+ Sample 10 - Sample 13 \& Sample 18 Z Sample 22 ₹ Sample 31

Polyethylene Waste Form Compressive Strength

50 wt\% Sodium Nitrate

Conditioned at $50^{\circ} \mathrm{C}, 3$ months

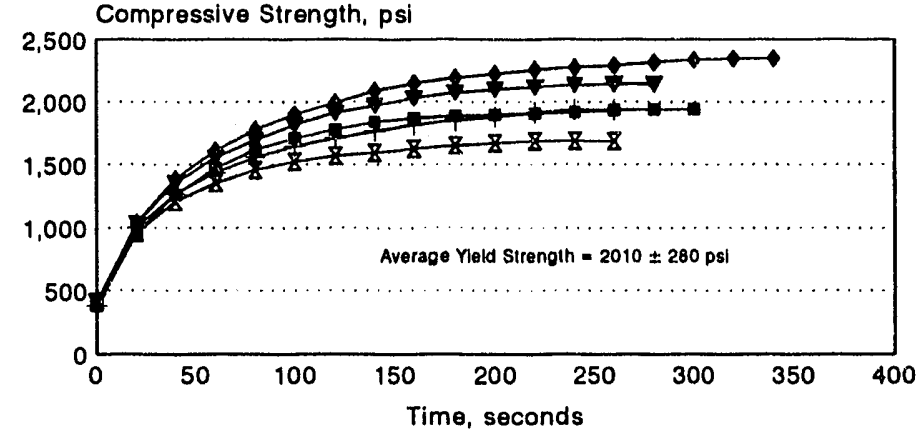

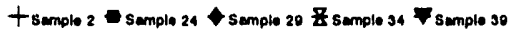

Polyethylene Waste Form Compressive Strength

$50 \mathrm{wt} \%$ Sodium Nitrate

Conditioned at $70^{\circ} \mathrm{C}, 3$ months

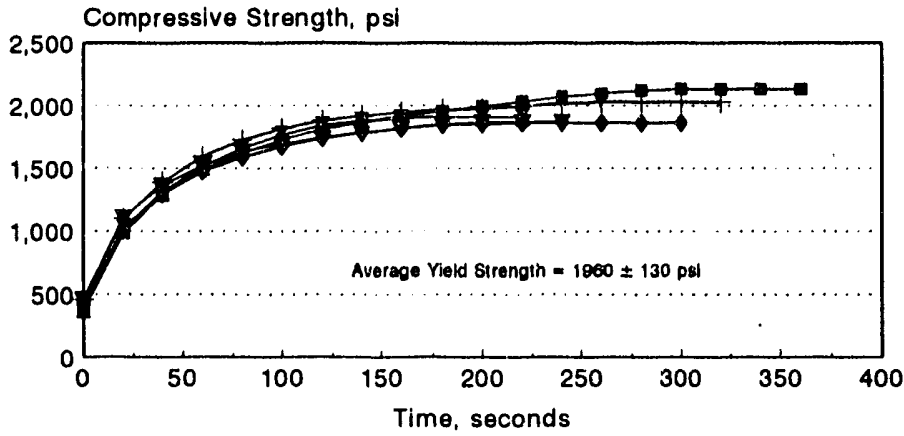

+ Sample 9 - Sample 21 Sample 27 \& Sample $32 *$ Sample 36

A -11 
Polyethylene Waste Form Compressive Strength 60 wt\% Sodium Nitrate

Control Specimens (Stored at Ambient Temp)

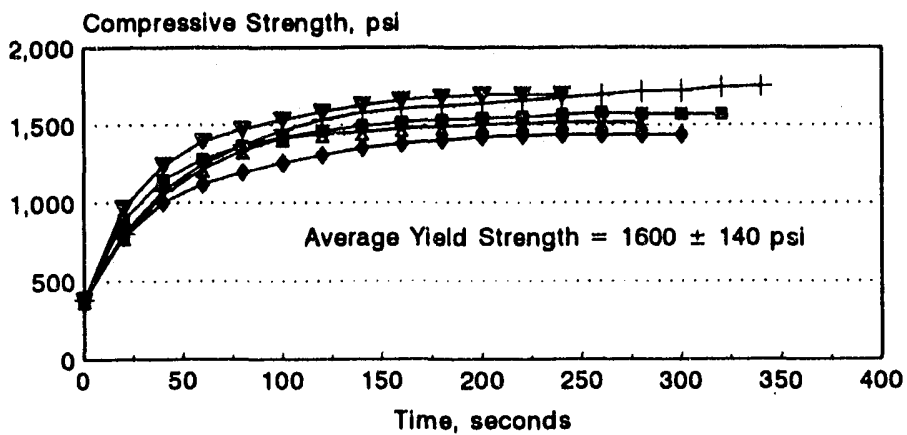

+ Semplo 25 Samplo 27 S Sample 30 Semplo 33 ₹ Samplo 38

Polyethylene Waste Form Compressive Strength

$60 w t \%$ Sodium Nitrate

Conditioned at $50^{\circ} \mathrm{C}, 3$ months

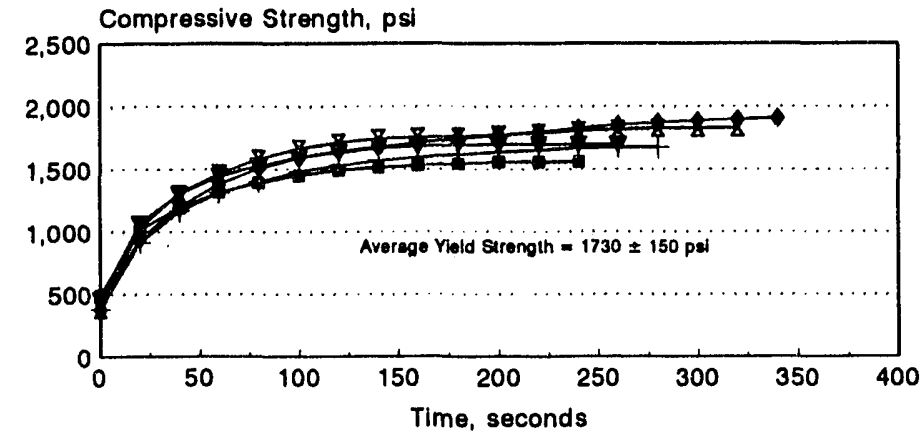

+ Sample 6 - Sample $23 \uparrow$ Sample 32 E Sample $39 \approx$ Sample 40

Polyethylene Waste Form Compressive Strength $60 \mathrm{wt} \%$ Sodium Nitrate

Conditioned at $70^{\circ} \mathrm{C}, 3$ months

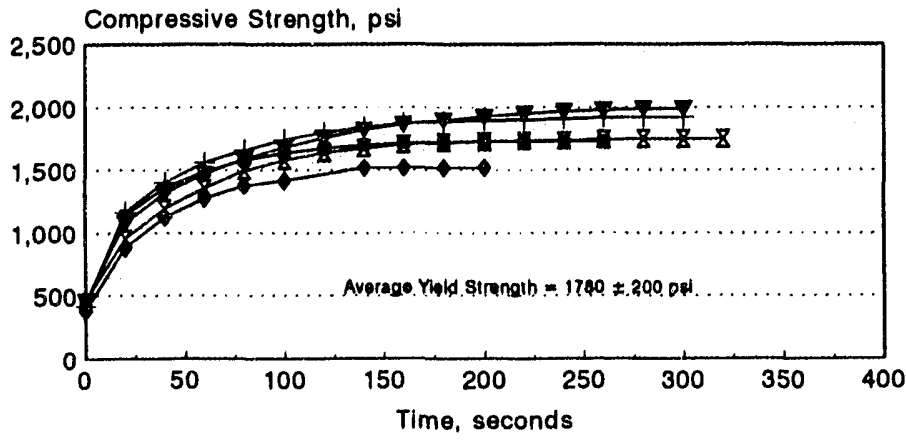

+ Sample 7 - Sample $14 \uparrow$ Sample 19 \& Sample 227 Sample 31

A -12 
Polyethylene Waste Form Compressive Strength

$70 w t \%$ Sodium Nitrate

Control Specimens (Stored at Ambient Temp)

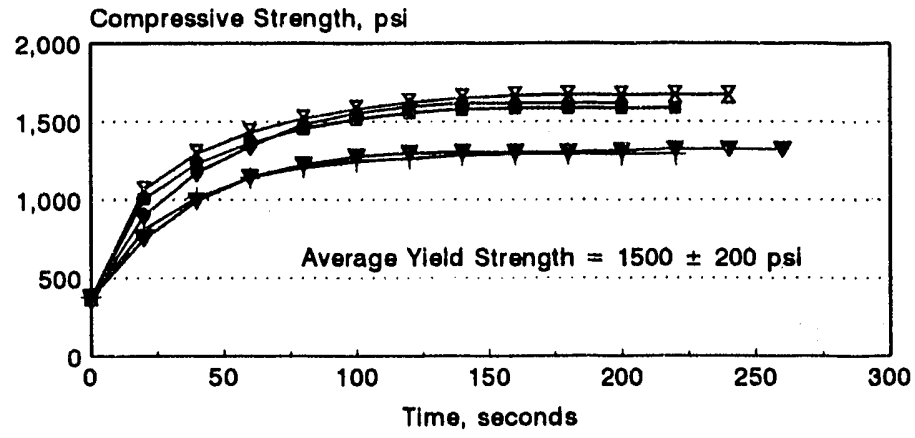

+ Sample 2 Sample 6 † Sample 11 Z Sample 17 ₹ Sample 31

Polyethylene Waste Form Compressive Strength $70 w t \%$ Sodium Nitrate

Conditioned at $50^{\circ} \mathrm{C}, 3$ months

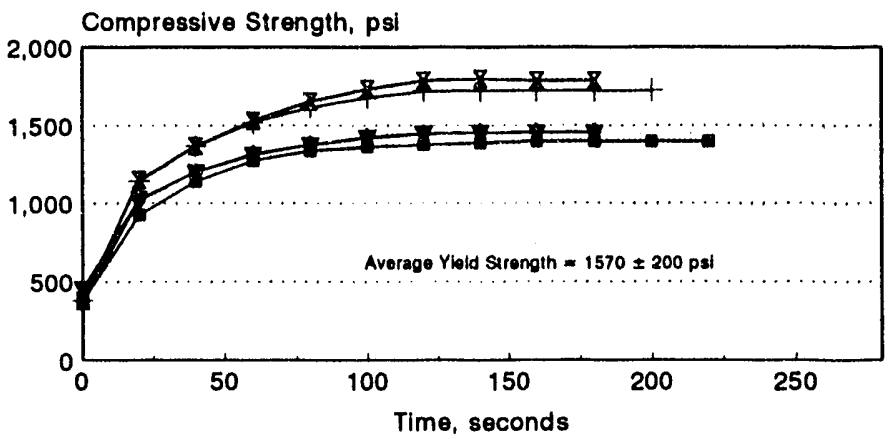

+ Sample 3 Sample 15 S Sample 30 Z Samplo $35 \%$ Samplo 37

\section{Polyethylene Waste Form Compressive Strength}

70 wt\% Sodium Nitrate

Conditioned at $70^{\circ} \mathrm{C}, 3$ months

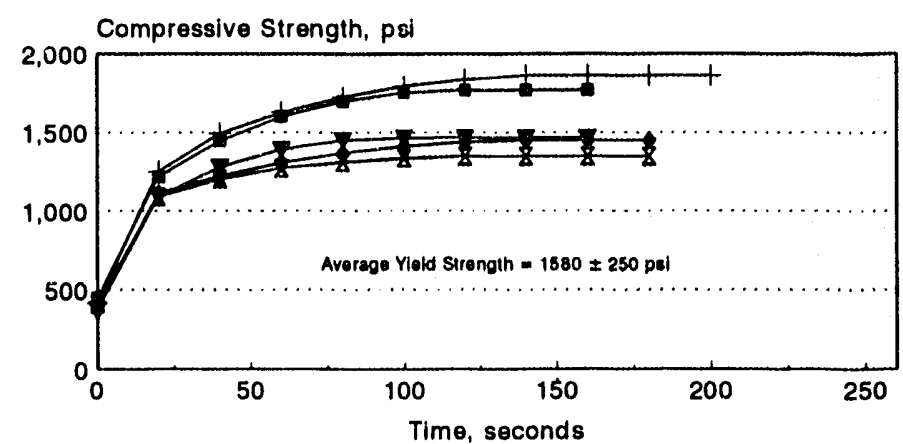

+ Sample 19 - Samplo $20 \diamond$ Sample 28 Z Samplo 29 ₹ Samplo 38

$$
\text { A }-13
$$



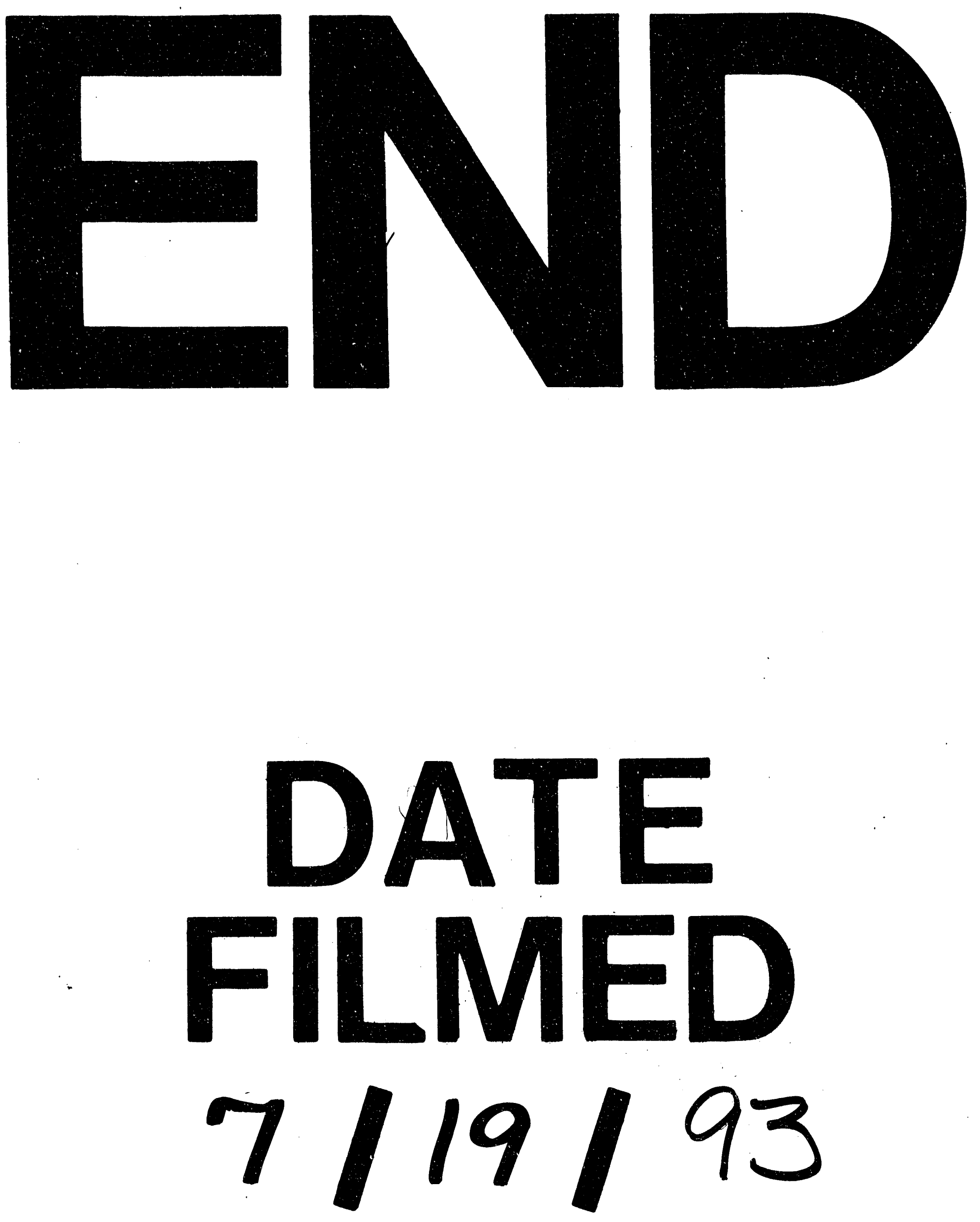

| 
